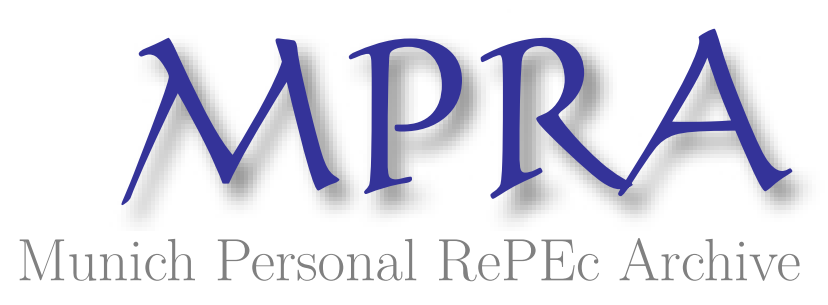

\title{
Volatility of a Seemingly Fixed Exchange Rate
}

Kocenda, Evzen

1995

Online at https://mpra.ub.uni-muenchen.de/70506/

MPRA Paper No. 70506, posted 07 Apr 2016 18:32 UTC 


\title{
Volatility of a Seemingly Fixed Exchange Rate
}

\author{
Evzen Kocenda \\ GE A, Prague, Czech Republic \\ and \\ University of Houston, Houston, U.S.A.
}

November 1995

\begin{abstract}
$\underline{\text { Abstract }}$
A conditional variance analysis is applied to study the exchange rate of the Czech crown. The crown is pegged to a currency basket with an imposed narrow band. The central bank's consistent policy enables the semi-fixed exchange rates to behave similarly to free ones. Their movements exhibit strong nonlinear dependency which is accounted for by an employment of the GARCH(1,1) model with daily dummies. The nonparametric BDS test proclaims accuracy of the model that filtered out nonlinearity and captured a forecastable structure present in the data.
\end{abstract}

\begin{abstract}
$\underline{\text { Abstrakt }}$
Analýza podmíneného rozptylu je pouzita ke studiu smenného kurzu ceské koruny, jejíz tesné spojení menovým košem vytvárí pouze úzké fluktuacní pásmo. Opatrení centrální banky umoznují, aby se cástecne fixní smenný kurz mohl chovat jako plovoucí. Chování smenného kurzu vykazuje silnou nelinearní závislost, která je vyhodnocena pomocí modelu GARCH $(1,1) \mathrm{s}$ denní "dummy" promennou. Neparametrický test BDS potvrzuje vhodnost volby tohoto modelu, který odstraní nelinearitu a umozní identifikaci struktury procesu.
\end{abstract}

Keywords: exchange rates, currency basket, nonlinearity, GARCH

JEL Classification: C22, F31, G10

I would like to thank D. Papell, D. Dechert, R. Susmel, and J. Fahy for their helpful comments on this paper. The usual disclaimer applies. 


\begin{abstract}
$\underline{\text { Abstract }}$
EEA95

Evzen KOCENDA*

"Volatility of a Seemingly Fixed Exchange Rate"

* GEA, Charkovska 13, 10100 Prague, Czech Republic

A conditional variance analysis is applied to study the exchange rate of the Czech crown. The crown is pegged to a currency basket with an imposed narrow band. The central bank's

consistent policy enables the semi-fixed exchange rates to behave similarly to free ones. Their movements exhibit strong nonlinear dependency which is accounted for by an employment of the GARCH(1,1) model with daily dummies. The nonparametric BDS test proclaims accuracy of the model that filtered out nonlinearity and captured a forecastable structure present in the data.
\end{abstract}

Keywords: exchange rates, currency basket, nonlinearity, GARCH 


\section{Introduction}

Several detailed studies have applied the original autoregressive conditional heteroskedastic (ARCH) model of Engle (1982) and its generalization (GARCH) developed by Bollerslev (1986) to access changing variances of exchange rates and their distribution. Knowledge of the exchange rates' behavior has important implications on the decisions made in the international financial environment. The opening of the new emerging markets in Central Europe has increased interest in exploring the behavior of the exchange rates of the region. Central European economies are undergoing unique transformations and their currencies are not yet fully convertible. For these reasons their exchange rate arrangements are different from those in the developed economies where exchange rates are free to float completely or within a band. This paper examines the behavior of the exchange rate of the Czech crown when pegged to a currency basket. This is an enrichment in the field because, so far, no research has applied the ARCH model to such an exchange rate.

The exchange rates in this paper are described both narratively and from a statistical point of view. A short explanation is provided on how the exchange rate movement is related to the currency basket peg. The peg is supposed to limit the overall instability of the currency and, hence, to stabilize the exchange rate. This is conditional on the central bank keeping the index of the currency basket within a narrow band without subjective tampering. In case of inconsistency, the pegged rates do not fully reflect the underlying processes in free exchange rates and further analysis is futile.

The tests that discover similarities between a pegged exchange rate system and the behavior of free floating exchange rates are presented, thus supporting the employment of an ARCH model. An autoregressive process is chosen as the underlying process in exchange rates movement because of the basket peg characteristic of the data. The GARCH $(1,1)$ model with daily dummy variables in both mean and variance equations is applied to model conditional variance in exchange rates in order to account for the heteroskedasticity. Estimates of the models are presented separately for the mean and variance equations along with statistical tests that show comparable as well as differing results from referenced studies.

A separate section elaborates on nonlinearity in exchange rate movement and uses an advanced nonparametric BDS statistic to test the results. The quantitative results are applied to the behavior of exchange rate and central bank policy. These features differentiate this paper from previous studies stressing instead the statistical presentation. 


\section{The Data}

The data consists of daily exchange rates of the Czech crown (CZK) to six major currencies during the period from January 2, 1991, to September 30, 1994. The split-up of the former Czechoslovakia on January 1, 1993, generated two separate currencies (the Czech crown and the Slovak crown) which replaced the former Czechoslovak crown. The entire series is refered to as the Czech crown because it (the CZK) followed the former stable path of the old Czechoslovak crown. After the monetary separation the Slovak crown has devalued considerably. The data was supplied by the Czech National Bank (CNB) in Prague. Six major currencies were selected for this study because of their importance in international trade and their inclusion in the currency basket to which the Czech crown is pegged. The six foreign currencies are: the British pound (GBP), the Austrian shilling (ATS), the German Mark (DEM), the U.S. dollar (USD), the Swiss franc (CHF), and the French franc (FRF). There are total of 953 daily observations for each currency. Figure 1 shows the evolution of the respective exchange rates over the whole period. The data is not stationary but is a first order integrated process. The rate of change is calculated by taking the logarithmic difference between two consecutive business days. Figure 2 represents the logarithmic first order differences of exchange rates, serves as a visual test for stationarity, and illustrates the periods of volatility.

Table 1 contains the summary statistics of the data. The means are fairly small, however, and their negative sign implies that the crown has on average slightly depreciated through time. The low variance indicates quite stable evolution. The range of daily changes is relatively small, with one exception. A drop of almost 5 percent of the GBP coincides with the time when the GBP left the European Monetary System. Unconditional distributions for the three rates show a typical property of a fat tail implying non-normal distribution as indicated by the fourth moment.

In order to complete a description of the data and to understand its behavior, the following section demonstrates how semi-fixed exchange rates in question are derived and why they are semi-fixed.

\section{Currency Basket and Its Relation to Exchange Rates}

The exchange rates described in the previous section are not completely free to float, as those of the developed economies are. In a sense they are actually fixed. To properly address the question of whether they behave in a similar fashion as free exchange rates, a short description and overall performance of the monetary instrument called a currency basket follows. 
The former Czechoslovakia started its economic transformation officially in 1991. From this point the role of the exchange rate could no longer be downplayed as in the former centrally planned economy. However, a certain degree of the reduction of relative volatility in the exchange rates' evolution was desirable in order to promote export, direct foreign investments, and generally favorable economic development during the transition to a free market economy. The shock of the transition needed to be buffered; therefore, to introduce a fully free exchange rate system initially would have been premature. A free exchange rate system requires that no restrictions on financial capital movement be imposed. This requires a strong mature economy with sufficient reserves of convertible currencies. During the early stages of the economic reform, the country did not satisfy these conditions and an eventual bank run could have caused vast damage. The situation called for a temporary anchor of the currency basket peg. More detailed discussion on the role of fixed exchange rates can be found in Svensson (1994).

When a currency is bound to several currencies via exchange rates in certain proportions, it is said that a currency is pegged to a "currency basket." According to the International Monetary Fund, a currency basket is categorized as a type of fixed exchange rate arrangement. The CNB introduced the basket system at its current general level at the beginning of 1991 .

The currency basket is usually described by the geometric average of absolute values, to capture the proportional changes and influences of respective currencies by their weights. The CNB constructed the basket as a weighted average of nominal exchange rates. Mathematically it creates a slight discrepancy by not fully using the importance of the respective currencies, which are represented by their weights. The change in value of the currency basket is measured by its index $I(t, w)$ which the CNB defined as:

$$
I(t, w)=\sum_{j=1}^{N} w_{j}\left[R_{j}(t) / R_{j}(0)\right]
$$

where $\mathrm{w}_{\mathrm{j}}$ is a weight $\left(\sum \mathrm{w}_{\mathrm{j}}=1\right), \mathrm{R}_{\mathrm{j}}(\mathrm{t})$ is a domestic exchange rate at time $\mathrm{t}$, and $\mathrm{R}_{\mathrm{j}}(0)$ is a domestic exchange rate at time 0 , e.g. the base exchange rate. Both rates are at a nominal level. In order to peg the home currency to a currency basket, the index must be fixed. In this case it means that index is set to be equal to one $[\mathrm{I}(\mathrm{t}, \mathrm{w})=1]$.

Table 2 illustrates three changes in weights and base rates that took place during the four year period. The weights represent the relative importance of the particular foreign currency in the turnover of the Czech balance of payments excluding banking operations. The band imposed on the basket was set at $\pm 0.5 \%$. The CNB managed to keep the index of the basket within the band 
during all three periods. The index was held on average at $0.9999,1.0011$, and 0.9952 for the respective periods. However, minor mismanagements occurred, as can be seen in Figure 3, which shows the evolution of the currency basket index over the entire period.

The two previous sections offered some characteristics of the semi-fixed exchange rates. The following section provides an analysis of why the semifixed exchange rates may exhibit periods of volatility and what kind of process is able to illustrate their movements.

\section{Testing for the Process in the Exchange Rates}

Many economic and especially financial variables reflect the stylized facts attributed to Mandelbrot (1963). These are: (1) unconditional distributions have thick tails, (2) variances change over time, and (3) large changes tend to be followed by large changes of either sign and small by small. These stylized facts are especially appealing in the context of high frequency financial data such as exchange rates and stock prices.

The distribution and statistical properties of daily exchange rates have been of considerable interest since exchange rates of major currencies started to float. The importance of this knowledge has very practical implications: the effects of exchange rate movement on international trade and capital flows, mean-variance analysis of international asset portfolios, and the pricing of options on foreign currencies. The opening of new emerging markets in Central Europe has lead to interest in the behavior of the exchange rates of these economies since they broaden frontiers in international investments. To know the statistical properties and to define the behavior of the particular currency may lower the risk involved in international financial activity.

The fat tails of the exchange rates distributions imply increased uncertainty, and this feature attracts attention. In order to account for the leptokurtosis, two different explanations were suggested in the literature, namely by Friedman and Vandersteel (1982). One idea suggests that the rates are independently drawn from a fat tail distribution that is fixed over time. The other view favors distributions that vary over time. Hsieh (1988) found strong statistical evidence to discriminate between the two competing theories. His evidence points to the rejection of the first hypothesis because of changing means and variances of daily rates. This feature can be best described by accounting for the conditional autoregressive heteroskedasticity in modeling the variance that was first introduced by Engle (1982). 
So far, the research interest has concentrated on free floating exchange rates. It is clear that it is not of too much use to study firmly fixed exchange rates in a time series context since they represent just series of equal numbers over a period of time. However, the behavior of semi-fixed exchange rates, which can be observed in the case of the currency basket arrangement, does not offer such a clear explanation. At first, due to the condition that the basket index be kept at some constant related to its construction and that deviation be allowed only within the band, exchange rates should closely follow their "master" currencies in many respects. On other hand, the exchange rates are likely to be exposed to the subjective actions of a central bank which may try to manipulate certain exchange rates within or outside the limits of the basket. The reason would be to pursue its own targeting policy or to smooth outside negative influences in order to maintain relative stability of exchange rates. Volatile periods may emerge from both motives mentioned above. The consistent monetary policy of the central bank with respect to the stable index is therefore an imperative in order to produce mathematically consistent semi-fixed exchange rates. Fortunately, this is the case for the Czech crown.

Milhøj (1987) modeled the distribution of daily deviations of the U.S. dollar to Special Drawing Rights (SDR) using a simple ARCH model. SDR is a composite of currencies since July 1, 1974. However, the U.S. dollar is not pegged to this basket and such a modeling does not involve the feature of a semi-fixed exchange rate. Therefore, the exchange rates of the Czech crown to other currencies represent an interesting modeling challenge.

The original ARCH model framework of Engle (1982) suggests that current volatility depends on past squared innovations in order to explain the tendency of large residuals to cluster together. Bollerslev (1986) extended the framework into a generalized autoregressive conditional heteroskedasticity model $(\mathrm{GARCH})$ where current volatility depends not only on past squared residuals but also on a lagged autoregressive component, e.g. lagged own variances. By deriving residuals $\varepsilon_{\mathrm{t}}$ from an underlying process that are conditioned by the information set $\Omega_{\mathrm{t}}$, a GARCH $(\mathrm{p}, \mathrm{q})$ process is given by

$$
\varepsilon_{\mathrm{t}} \mid \Omega_{\mathrm{t}-1} \sim \mathrm{N}\left(0, \mathrm{~h}_{\mathrm{t}}\right)
$$

with conditional autoregressive variance

$$
\mathrm{h}_{\mathrm{t}}=\omega_{0}+\sum_{\mathrm{j}=1}^{\mathrm{p}} \alpha_{\mathrm{j}} \varepsilon_{\mathrm{t}-\mathrm{j}}^{2}+\sum_{\mathrm{j}=1}^{\mathrm{q}} \beta_{\mathrm{j}} \mathrm{h}_{\mathrm{t}-\mathrm{j}}
$$

Whether the ARCH process described above is present in the data can be detected by subsequent tests. In order to remove any linear structure in the data, 
an autoregressive filter is applied. Each series is modeled as an autoregressive process of the form

$$
\mathrm{r}_{\mathrm{t}}=\mathrm{a}_{0}+\sum_{\mathrm{i}=1}^{10} \mathrm{a}_{\mathrm{i}} \mathrm{r}_{\mathrm{t}-\mathrm{i}}+\varepsilon_{\mathrm{t}}
$$

where $\varepsilon_{\mathrm{t}}$ is independently and identically distributed (iid). The Akaike Information Criterion (AIC) method of Akaike (1974) was employed to determine the appropriate number of lags.

Table 3 shows the results from two independent tests performed on residuals from the mean equation [AR(10)] to detect the presence of an $\mathrm{ARCH}$ process described above. A Lagrange-multiplier test suggested by Engle (1982) tests a null hypothesis that no ARCH process is present in the data. The values of $\mathrm{LM}(10)$ are distributed according to the chi-squared distribution with 10 degrees of freedom and the null hypothesis can be decisively rejected at any confidence level for all six rates.

A Ljung-Box test against higher order serial correlation was performed for up to the tenth order. The values of Ljung-Box $Q$ statistic are distributed asymptotically according to the chi-squared distribution with 10 degrees of freedom. The values for the first moments are extremely low and are not statistically significant at any reasonable level for any of the six currencies. This fact indicates that there is no higher order serial correlation present in the data. On the other hand, the values of the Ljung-Box Q statistic for absence of serial correlation in squared residuals are high enough above a $1 \%$ significance level to indicate the presence of serial correlation here. The absence of serial dependence in the first conditional moments and its strong presence in the conditional second moments indicate an $\mathrm{ARCH}$ process.

Despite the fact that the tests were performed using the autoregressive process with 10 lags, the results of both tests are not sensitive to any particular choice of lags, as they were replicated for control purpose with different structures.

The values of the unconditional sample kurtosis exceed a normal value in the case of three currencies. This fact, along with the results of previous tests, shows that an autoregressive process appears to account for the serial correlation properties of the daily data. However, it does not adequately describe the heteroskedasticity or the large kurtosis present in the daily rates. The next step is to employ an ARCH model with conditionally distributed errors and daily dummy variables in both the conditional mean and conditional variance equations. 


\section{Modeling Conditional Variance}

Brock, Hsieh, and LeBaron (1993), p. 130, point out that a prevalent view in the literature is that exchange rates follow a random walk. However, no strong statistical evidence has emerged to confirm or refute this view so far. The research done with exchange rates and security prices uses the random walk as well as different univariate processes. When taking into account the basket pegged character of the exchange rates in the data set, the possibility of a specific underlining process can not be overlooked.

An autoregressive process was chosen as a proxy to model an underlying process in data. The AIC method was employed to determine the appropriate number of lags. AR(10) structure was also the efficient way to filter the data so that a model yielded residuals free of autocorrelation and seasonality as well. To capture plausible changes of the distribution in different days during a business week, appropriate day-of-the-week dummy variables were employed. The specification of the model resulted into the following mean equation:

$$
\mathrm{r}_{\mathrm{t}}=\mathrm{a}_{0}+\sum_{\mathrm{i}=1}^{10} \mathrm{a}_{\mathrm{i}} \mathrm{r}_{\mathrm{t}-\mathrm{i}}+\gamma_{1} \mathrm{~d}_{\mathrm{MO}, \mathrm{t}}+\gamma_{2} \mathrm{~d}_{\mathrm{TU}, \mathrm{t}}+\gamma_{3} \mathrm{~d}_{\mathrm{WE}, \mathrm{t}}+\gamma_{4} \mathrm{~d}_{\mathrm{TH}, \mathrm{t}}+\gamma_{5} \mathrm{~d}_{\mathrm{HO}, \mathrm{t}}+\varepsilon_{\mathrm{t}}
$$

where, $\varepsilon_{\mathrm{t}} \mid \Omega_{\mathrm{t}-1} \sim \mathrm{D}\left(0, \mathrm{~h}_{\mathrm{t}}\right)$, and variance equation:

$$
\mathrm{h}_{\mathrm{t}}=\omega+\alpha \varepsilon_{\mathrm{t}-1}^{2}+\beta \mathrm{h}_{\mathrm{t}-1}+\phi_{1} \mathrm{~d}_{\mathrm{MO}, \mathrm{t}}+\phi_{2} \mathrm{~d}_{\mathrm{TU}, \mathrm{t}}+\phi_{3} \mathrm{~d}_{\mathrm{WE}, \mathrm{t}}+\phi_{4} \mathrm{~d}_{\mathrm{TH}, \mathrm{t}}+\phi_{5} \mathrm{~d}_{\mathrm{HO}, \mathrm{t}}
$$

where $d_{\mathrm{MO}, \mathrm{t}}, \mathrm{d}_{\mathrm{TU}, \mathrm{t}}, \mathrm{d}_{\mathrm{WE}, \mathrm{t}}, \mathrm{d}_{\mathrm{TH}, \mathrm{t}}$ are dummy variables for Monday, Tuesday, Wednesday, and Thursday, and $\mathrm{d}_{\mathrm{HO}, \mathrm{t}}$ is the number of holidays (excluding weekends) between successive business days.

The restrictions on the parameters in the variance equation require that

$$
\omega>0, \alpha \geq 0, \beta \geq 0 \text {. }
$$

Further, when

$$
\alpha+\beta<1,
$$

the unconditional variance is finite and the stationarity is ensured by not having unit root as shown by Bollerslev (1986).

Estimation of the model is performed by using a log-likelihood function of the form

$$
L=\left(-0.5 \log h_{t}-0.5 \varepsilon_{t}^{2} / h_{t}\right)
$$


Coefficients of the day-of-the-week dummies are expected to be fairly small and therefore non-negativity restrictions are not imposed on them. The maximum likelihood estimates are obtained by using a numerical optimization algorithm described by Berndt, Hall, Hall, and Hausman (1974).

The results from the estimation are divided into two separate tables for better accessibility. Table 4 contains estimated parameters from the mean equation. There are only a few parameters within the lag range from 1 to 9 that are statistically different from zero. In four cases, however, coefficients of lag 10 are highly significant. This confirms the original tests, suggesting an AR(10) structure in the data. Lag 10 means exactly two business weeks' memory of the market.

Table 5 contains results from the iterative estimation of the variance equation which is of primary interest. The reason is as follows: If a conditional variance is changing through time in a predictable way, then the correct modeling of such a variance would yield better estimates of the parameters in the mean equation. It would improve estimates of confidence intervals around the mean forecasts as well. Restrictions put on the coefficients $\omega, \alpha$, and $\beta$ are satisfied, as well as finite conditional variance condition of $\alpha+\beta<1$. However, Nelson (1991) has shown that even for a region of parameter value beyond this boundary (e.g. $\alpha+$ $\beta>1$ ) the conditional variance process will be strictly stationary and ergodic.

Coefficients of constant $\omega$ are small and mostly insignificant. Estimates of the lagged squared residuals $\alpha$ and the lagged variance $\beta$ are large and comparable with those found in the literature. All of them are significantly different from zero at the $1 \%$ level. The magnitude of the lagged variance in all six currencies produces irrefutable evidence of the importance that this lagged term must be included in the equation of the conditional variance.

The sum of the estimated values of $\alpha$ and $\beta$ amounts on average to 0.937 for all six currencies. This fact might suggest the employment of an Integrated GARCH $(1,1)$ model. The IGARCH model imposes the restriction $\alpha+\beta=1$ on the coefficients and provides an even simpler characterization of exchange rates in question. However, the IGARCH model imposes complete persistence of a shock for an infinite time horizon. The covariance stationary GARCH model, on the contrary, implies relatively rapid exponential decay of the shock. Due to the fact that the currency basket peg dilutes external shocks in the free rates and other influences proportionately according to the weights, their full impact is eventually damped out within a relatively short period of time. This is fully in accord with the character of the data, and therefore, justifies the use of the GARCH model as opposed to the IGARCH one. Further discussion on this subject can be found in Bollerslev and Engle (1993). 
Estimates of the day-of-the-week dummy coefficients are fairly small, despite the fact that all six currencies show evidence of systematic daily patterns in the conditional variance. Similar daily effects were reported by Baillie and Bollerslev (1989) and Hsieh (1988). They are clearly divided into positive and negative effects across days in the week with corresponding daily magnitude levels. Monday, Wednesday, and Thursday show negative effects, while Tuesday and Holiday show positive effects. The Tuesday effect is statistically evident for four currencies and the Wednesday effect is strongly evident for five of them.

The basket peg causes the exchange rates of the CZK to lag one day behind the changes in currencies to which the basket is pegged. This is because free exchange rates at the market in Frankfurt at time $(t)$ are used to set the currency basket and exchange rates of the CZK at time $(t+1)$. Due to the one-day lag, the Tuesday effect captures reaction on the accumulation of information in the financial markets over the weekend. When modeling free exchange rates, it would be the Monday effect that should capture this phenomenon because of the lack of a time lag. The Wednesday effect may be understood as a natural correction of the financial markets after a possible over-reacting on accumulated information a day before, as seen on Tuesday in the free exchange rate countries.

\section{The Fit of the Model and Testing for Nonlinearity}

The overall fit of the model is accessed by diagnostic tests on standardized residuals $\mathrm{z}_{\mathrm{t}}$ that are constructed as

$$
\mathrm{z}_{\mathrm{t}}=\varepsilon_{\mathrm{t}} / \mathrm{h}_{\mathrm{t}}^{\frac{1}{2}}
$$

where $\varepsilon_{t}$ is the residual of the mean equation (5), and $h_{t}$ is the estimated conditional variance from (6). The tests and statistics are shown in Table 6. The means are close to zero and variances tend towards unity for the exchange rates residuals. Under these conditions it shows that equations (5) and (6) are correctly specified. Ljung-Box tests document that first order serial dependency is not present at all. Second order dependence is generally missing as well; however, it is detected at a 5\% level in standardized residuals for the ATS and the FRF. Kurtosis dropped for all currencies except the USD, though its decrease in the case of the GBP and the DEM was not large enough to fit into a normal distribution. Kurtosis of the ATS, the CHF, and the FRF decreased sufficiently to fit into normal distribution. 
The standardized residuals were examined with a BDS test of Brock, Dechert, and Scheinkman (1987) as well. The BDS test is a nonparametric test of null hypothesis that data is independently and identically (iid) distributed. The technique enables testing for nonlinear dependence and uses the concept of the correlation integral employed by Grassberger and Procaccia (1983) to distinguish between chaotic deterministic systems and stochastic systems.

The correlation integral $\mathrm{C}_{\mathrm{m}}(\varepsilon, \mathrm{T})$ is defined as

$$
C_{m}(\varepsilon, T)=\#\left\{(i, j)\left\|x_{i}^{m}-x_{j}^{m}\right\|<\varepsilon \wedge(i \neq j)\right\} / T(T-1)
$$

where $\mathrm{m}$ is a spatial embedding dimension, $\mathrm{T}=\mathrm{N}-(\mathrm{m}-1)=$ the number of $\mathrm{m}$ histories that can be constructed out of series of length $N$, and $\varepsilon$ is the chosen tolerance distance. The correlation integral measures the fraction of pairs of histories $\left(\mathrm{x}_{\mathrm{i}}^{\mathrm{m}}, \mathrm{x}_{\mathrm{j}}^{\mathrm{m}}\right)$ that lie within a distance of $\varepsilon$ from each other for specific spatial dimension $\mathrm{m}$.

The BDS test checks whether the data is distributed iid and the employed procedure has power against both deterministic and stochastic systems. Similarly, as in Brock, Hsieh, and LeBaron (1993) or Brock, Dechert, Scheinkman, and LeBaron (1994), the BDS statistic can be defined as

$$
\operatorname{BDS}_{\mathrm{m}, \mathrm{T}}(\varepsilon)=\mathrm{T}^{\frac{1}{2}}\left[\mathrm{C}_{\mathrm{m}, \mathrm{T}}(\varepsilon)-\mathrm{C}_{\mathrm{i}, \mathrm{T}}(\varepsilon)^{\mathrm{m}}\right] / \sigma_{\mathrm{m}, \mathrm{T}}(\varepsilon)
$$

where $\mathrm{C}_{\mathrm{i}}$ is a number of matches with respect to particular distance $\varepsilon$ and spatial dimension $\mathrm{m}$ with dimension $\mathrm{m}$. The distance $\varepsilon$ is chosen as a ratio of the standard deviation., and $\sigma_{\mathrm{m}, \mathrm{T}}(\varepsilon)$ is a standard deviation of the statistic varying

By detecting pairs of histories that cluster together within a specific range $\varepsilon$ too often, the BDS test is able to reveal hidden patterns which should not occur in a truly randomly distributed data. A "pattern" in this case is defined as an occurrence of two histories that lie within a certain distance $\varepsilon$ of each other for different spatial dimensions $m$. Further detailed explanation and application of the BDS test can be found in the original paper as well as in representative studies by Brock and Dechert (1988), Hsieh (1989), Hsieh (1991), Brock, Hsieh, and LeBaron (1993), and Brock, Dechert, Scheinkman, and LeBaron (1994). The software program of Dechert (1987) was used to compute the BDS statistic.

The BDS test is able to reveal hidden patterns in seemingly random numbers. This can be illustrated by results from the BDS test performed on the stationary first logarithmic differences to test for the nonlinearity in the data. The results in 
Table 7 support decisive rejection of the hypothesis that logarithmic first differences of the exchange rates are iid for all currencies, thus producing evidence of a nonlinear dependence among them.

The subsequent application of the BDS test on the standardized residuals has a strong implication. If the standardized residuals originate from a correctly specified model of the mean with a correctly specified model of the conditional variance, they should not contain any other useful forecastable structure. In other words standardized residuals derived from such a model should become white noise.

Table 8 shows the results of the BDS test on standardized residuals. The results can be interpreted with the help of Table 9, which contains quantiles of the BDS statistic of standardized residuals from the $\operatorname{GARCH}(1,1)$ model of exchange rates. The asymmetric distribution was derived by Brock, Hsieh, and LeBaron (1993), p. 278, after 2000 replications (the table, however, states values for $\varepsilon=$ 1 and 0.5 only). For distance $\varepsilon=1$ the test reveals no evidence of nonlinear dependence for four currencies: the ATS, the DEM, the CHF, and the FRF. However, the critical values are exceeded for spatial dimensions $\mathrm{m}=3,4,5$, and 10 in the case of the GBP which shows quite high values for all dimensions in any event, and for $\mathrm{m}=4$ and 5 in the case of the USD. This indicates the existence of some more complex dimensional structures governing the behavior of these particular rates. In the case of the USD it is a marginal decision though. A missing nonlinear term is to be added to better the model. At the distance $\varepsilon=$ 0.5 a nonlinear dependence is not detected in general. The critical value is exceeded at the dimensional level of $m=3$ in the rate of the GBP. In no case is the critical value exceeded at the highest dimensional level. If it were, it would have been for a different reason. As the spatial dimension $m$ increases, the number of pairs of histories that lie within the distance $\varepsilon$ decreases rapidly. The lack of available data, therefore, causes the test to go beyond the statistical range and distortion is likely to occur.

Figure 4 presents the results of the BDS test in a graphical form which exploits the scaling laws widely used in physics. Graphs actually represent ratios of standardized number of matches $(\mathrm{Cm} /[\mathrm{N}(\mathrm{N}-1) / 2])$ with respect to particular distance $(\varepsilon)$ for different spatial dimensions (m). Unlike in Table 8, a large set of $\varepsilon$ is used, ranging from 0.25 to 1.0 (41 in total). The BDS test was first conducted on a set of random numbers and is presented by a typical picture of fan-like trajectories decreasing at a sharper angle as the spatial dimension $\mathrm{m}$ gets larger. The slope of the respective trajectories equals $\mathrm{m}$ when averaging their rugged portions. The graphs which use standardized residuals as entries show remarkable similarity with those using random numbers. The strong difference can be found in the case of the GBP for higher spatial dimensions 
(from 7 to 10). One would expect this with respect to the results from Table 8 . The rate of the USD reveals only marginal differences.

It can be concluded that the model fits all six currencies very well, but the GBP requires some nonlinear improvement. Diagnostic tests show that the GARCH $(1,1)$ model is capable of accounting for most of the nonlinearity in the particular set of exchange rates.

\section{Conclusions}

Exchange rates of the Czech crown to the six major currencies evolved relatively steadily throughout the researched period. Due to their dependency on the currency basket, they are of the semi-fixed character. They showed remarkable similarities in behavior and statistical characteristics with those exchange rates that are free to float. This is to be attributed to the consistent policy of the central bank, which kept the basket index relatively unchanged within the $\pm 0.5 \%$ band. The exchange rates became stationary after the first logarithmic differencing and were shown not to be identically and independently distributed. Their conditional first moments are linearly independent; however, non-linear dependency was detected in conditional second moments. These facts along with the Lagrange-multiplier test confirmed the presence of an $\mathrm{ARCH}$ process in the data.

The GARCH(1,1) model was employed to capture the properties of the exchange rates and to model their conditional variance along with the day-ofthe-week effects. The mean equation of the model exhibits a strong statistical significance at the level of the tenth lag, which indicates a two-business-week memory of the market. The variance equation shows highly significant coefficients of lagged residuals and own variance. Altogether it is shown that change in a rate is very closely related to its conditional variance. Strong Wednesday and Tuesday effects uncover a significant sequential responsiveness to the information flow within the financial markets.

Tests performed on the standardized residuals from the $\operatorname{GARCH}(1,1)$ model revealed nonexistence of both first and second order serial dependency. However, the latter was detected at a 5\% level for two currencies. The model accounted for a decrease in kurtosis for five currencies, but in two cases only marginally so.

An advanced nonparametric BDS test revealed the existence of nonlinear dependency in exchange rates. Standardized residuals, on the contrary, revealed a lack of such a dependency and became white noise. The only exception is the GBP (and marginally the USD) where a nonlinear component should be added 
to improve the model. The particular model accounted for most of the nonlinearity in the data and the other nonlinear model is not likely to be able to pick up more of the forecastable structure from a time series. An application of conditional heteroskedasticity proved to be an efficient tool to analyze semifixed exchange rates managed under strict discipline. 


\section{REFERENCES}

Akaike, H. 1974. "A New Look at the Statistical Model Identification," IEEE Transactions on Automatic Control 19: 716-723.

Baillie, R. T., and T. Bollerslev. 1989. "The Message in Daily Exchange Rates:A Conditional Variance Tale," Journal of Business and Economic Statistics 7: 297-305.

Berndt, E. K., B. H. Hall, R. E. Hall, and J. A. Hausman. 1974. "Estimation of Inference in Nonlinear Structural Models," Annals of Economic and Social Measurement 4: 653-665.

Bollerslev, T. 1986. "Generalized Autoregressive Conditional Heteroskedasticity," Journal of Econometrics 31: 307-327.

Bollerslev, T., and R. F. Engle. 1993. "Common Persistence in ConditionalVariances," Econometrica 61: 167-186.

Brock, W., and W. Dechert. 1988. "A General Class of Specification Tests: The Scalar Case," in the Business and Economics Statistics Section of the Proceeding of the American Statistical Society: 70-79.

Brock, W., W. Dechert, and J. Scheinkman. 1987. "A Test for Independence Based on the Correlation Dimension," University of Wisconsin at Madison, Department of Economics Working Paper.

Brock, W., W. Dechert, J. Scheinkman, and B. LeBaron. 1994. "A Test for Independence Based on the Correlation Dimension," forthcoming in Econometric Reviews.

Brock, W. A., D. A. Hsieh, and B. LeBaron. 1993. "Nonlinear Dynamics, Chaos, and Instability: Statistical Theory and Economic Evidence," The MIT Press, Cambridge, MA.

Dechert, W. D. 1987. "A Program to Calculate BDS Statistics for the IBM PC," Department of Economics, University of Houston.

Engle, R. F. 1982. "Autoregressive Conditional Heteroskedasticity with Estimates of the Variance of United Kingdom Inflation," Econometrica 50: 987-1007.

Friedman, D., and S. Vandersteel. 1982. "Short-Run Fluctuations in Foreign Exchange Rates," Journal of International Economics 13: 171-186.

Grassberger, P., and I. Procaccia. 1983. "Measuring the Strangeness of Strange Attractors," Physica 9D: 189-208.

Hsieh, D. A. 1988. "Statistical Properties of Daily Exchange Rates: 19741983," Journal of International Economics 24: 129-145.

—.1989. "Testing for Nonlinear Dependence in Daily Foreign Exchange Rates," Journal of Business 62: 339-368.

- 1991. "Chaos and Nonlinear Dynamics: Application to Financial Markets," Journal of Finance 46: 1839-1877.

Ljung, G. M., and G. E. P. Box. 1978. "On a Measure of Lack of Fit in Time Series Models,” Biometrika 65: 297-303. 
Mandelbrot, B. 1963. "The Variation of Certain Speculative Prices," Journal of Business 36: 394-419.

Milhøj, A. 1987. "A Conditional Variance Model for Daily Deviations of an Exchange Rate," Journal of Business and Economic Statistics 5: 99-103.

Nelson, D. A. 1991. "Conditional Heteroskedasticity in Asset Returns: A New Approach," Econometrica 59: 347-370.

Svensson, L. E. O. 1994. "Fixed Exchange Rates as a Means to Price Stability: What Have We Learned?" European Economic Review 38: 447-468. 


\section{TABLES}

Table 1

Summary Statistics of Log Price Changes:

$$
\mathrm{r}_{\mathrm{t}}=\log \left(\mathrm{R}_{\mathrm{t}} / \mathrm{R}_{\mathrm{t}-1}\right) * 100
$$

\begin{tabular}{ccccccc}
\hline Statistics & GBP & ATS & DEM & USD & CHF & FRF \\
\hline Mean & -0.02163 & -0.00242 & -0.00416 & 0.00534 & -0.00156 & -0.00447 \\
\hline Variance & 0.23785 & 0.12908 & 0.11577 & 0.22176 & 0.20454 & 0.12005 \\
\hline Skewness & -1.68703 & -0.40586 & -0.57688 & 0.34574 & -0.16915 & -0.76434 \\
\hline Kurtosis & 16.2077 & 2.35196 & 3.21914 & 1.65811 & 2.57694 & 6.27226 \\
\hline Maximum & 1.99089 & 1.53259 & 1.28961 & 2.45490 & 2.28472 & 1.49497 \\
\hline Minimum & -4.9373 & -1.19121 & -1.73237 & -1.69109 & -2.34774 & -2.75034 \\
\hline
\end{tabular}

Table 2

Basket Composition, Currency Weights, and Base Rates across Periods

\begin{tabular}{cccccccc}
\hline Period & & GBP & ATS & DEM & USD & CHF & FRF \\
\hline Jan. 1,1991-Jan. 1, 1992 & Weight & 0.0424 & 0.1235 & 0.4552 & 0.3134 & 0.0655 & - \\
\hline & Base Rate & 52.50 & 2.59 & 18.23 & 28.00 & 21.34 & - \\
\hline Jan. 2, 1992-May 2, 1993 & Weight & - & 0.0807 & 0.3615 & 0.4907 & 0.0379 & 0.0292 \\
\hline & Base Rate & - & 2.61 & 18.35 & 27.84 & 20.57 & 5.37 \\
\hline $\begin{array}{c}\text { May 3, 1993-Sep. 30, } \\
\text { 1994 }\end{array}$ & Weight & - & - & 0.6500 & 0.3500 & - & - \\
\hline & & & & & & & \\
\hline & Base Rate & - & - & 17.995 & 28.443 & - & - \\
\hline
\end{tabular}

Weights add up to 1 and represent the relative importance of a particular currency in the balance of payments. Base rates are constant over the respective period.

Table 3

Testing for Conditional Heteroskedasticity and Serial Correlation

\begin{tabular}{ccccccc}
\hline Statistics & GBP & ATS & DEM & USD & CHF & FRF \\
\hline LM $(10)$ & 77.00 & 114.44 & 82.34 & 51.06 & 77.49 & 96.01 \\
\hline $\mathrm{Q}(10)$ & 0.3536 & 0.0964 & 0.0936 & 0.282 & 0.0104 & 0.1987 \\
\hline $\mathrm{Q}^{2}(10)$ & 110.05 & 156.94 & 130.32 & 64.97 & 94.24 & 135.09 \\
\hline Skewness & -1.441 & -0.404 & -0.674 & 0.326 & -0.179 & -0.854 \\
\hline Kurtosis & 14.600 & 2.394 & 3.523 & 1.815 & 2.561 & 6.474 \\
\hline
\end{tabular}

LM: Lagrange-multiplier test by Engle (1982), Q: Ljung-box test against higher order serial correlation by Ljung-Box (1978), $\chi^{2}$ critical value at $1 \%$ level with 10 d.f. is 23.21 
Table 4

Estimating the Mean Equation for $\operatorname{GARCH}(1,1)$

$$
\mathrm{r}_{\mathrm{t}}=\mathrm{a}_{0}+\sum_{\mathrm{i}=1}^{10} \mathrm{a}_{\mathrm{i}} \mathrm{r}_{\mathrm{t}-10}+\sum_{\mathrm{j}=1}^{5} \gamma_{\mathrm{j}} \mathrm{d}_{\mathrm{jt}}+\varepsilon_{\mathrm{t}}
$$

\begin{tabular}{|c|c|c|c|c|c|c|}
\hline $\begin{array}{c}\text { Estimates and } \\
\text { statistics } \\
\end{array}$ & GBP & ATS & DEM & USD & $\mathrm{CHF}$ & FRF \\
\hline $\mathrm{a}_{0}$ & $\begin{array}{l}-0.000529 \\
(0.000355)\end{array}$ & $\begin{array}{c}-0.000123 \\
(0.000261)\end{array}$ & $\begin{array}{l}-0.000208 \\
(0.000248)\end{array}$ & $\begin{array}{l}-0.000243 \\
(0.000343)\end{array}$ & $\begin{array}{c}-0.000581 \\
(0.000331)\end{array}$ & $\begin{array}{l}-0.000284 \\
(0.000252)\end{array}$ \\
\hline$a_{1}$ & $\begin{array}{c}0.0270 \\
(0.0326) \\
\end{array}$ & $\begin{array}{l}-0.1070^{\mathrm{a}} \\
(0.0328) \\
\end{array}$ & $\begin{array}{l}-0.0446 \\
(0.0327) \\
\end{array}$ & $\begin{array}{l}-0.0155 \\
(0.0326) \\
\end{array}$ & $\begin{array}{l}-0.0564 \\
(0.0329) \\
\end{array}$ & $\begin{array}{c}0.0024 \\
(0.0327) \\
\end{array}$ \\
\hline $\mathrm{a}_{2}$ & $\begin{array}{c}0.0569^{c} \\
(0.0326) \\
\end{array}$ & $\begin{array}{l}-0.0271 \\
(0.0330) \\
\end{array}$ & $\begin{array}{c}0.0304 \\
(0.0337) \\
\end{array}$ & $\begin{array}{c}0.0460 \\
(0.0326) \\
\end{array}$ & $\begin{array}{l}-0.0190 \\
(0.0328) \\
\end{array}$ & $\begin{array}{l}-0.0217 \\
(0.0327) \\
\end{array}$ \\
\hline$a_{3}$ & $\begin{array}{c}0.0302 \\
(0.0326)\end{array}$ & $\begin{array}{c}0.0489 \\
(0.0330) \\
\end{array}$ & $\begin{array}{c}-0.0227 \\
(0.0327)\end{array}$ & $\begin{array}{c}-0.0154 \\
(0.0326)\end{array}$ & $\begin{array}{c}-0.0307 \\
(0.0328)\end{array}$ & $\begin{array}{c}0.0122 \\
(0.0326)\end{array}$ \\
\hline $\mathrm{a}_{4}$ & $\begin{array}{c}0.0451 \\
(0.0326) \\
\end{array}$ & $\begin{array}{c}0.0397 \\
(0.0330) \\
\end{array}$ & $\begin{array}{c}0.0592 \\
(0.0326) \\
\end{array}$ & $\begin{array}{c}0.0448 \\
(0.0325) \\
\end{array}$ & $\begin{array}{c}0.0466 \\
(0.0328) \\
\end{array}$ & $\begin{array}{c}0.0517 \\
(0.0325) \\
\end{array}$ \\
\hline$a_{5}$ & $\begin{array}{l}-0.0400 \\
(0.0327) \\
\end{array}$ & $\begin{array}{c}0.0214 \\
(0.0330) \\
\end{array}$ & $\begin{array}{c}0.0283 \\
(0.0327) \\
\end{array}$ & $\begin{array}{c}0.0151 \\
(0.0326) \\
\end{array}$ & $\begin{array}{c}0.0018 \\
(0.0328) \\
\end{array}$ & $\begin{array}{c}0.0214 \\
(0.0325)\end{array}$ \\
\hline$a_{6}$ & $\begin{array}{c}-0.0165 \\
(0.0326) \\
\end{array}$ & $\begin{array}{r}-0.0533 \\
(0.0330) \\
\end{array}$ & $\begin{array}{c}-0.0551 \\
(0.0327) \\
\end{array}$ & $\begin{array}{c}-0.0421 \\
(0.0326) \\
\end{array}$ & $\begin{array}{r}-0.0130 \\
(0.0328) \\
\end{array}$ & $\begin{array}{c}-0.0233 \\
(0.0325) \\
\end{array}$ \\
\hline$a_{7}$ & $\begin{array}{l}-0.0536 \\
(0.0325) \\
\end{array}$ & $\begin{array}{l}-0.0183 \\
(0.0329) \\
\end{array}$ & $\begin{array}{l}-0.0188 \\
(0.0325) \\
\end{array}$ & $\begin{array}{l}-0.0001 \\
(0.0323) \\
\end{array}$ & $\begin{array}{c}0.0232 \\
(0.0328) \\
\end{array}$ & $\begin{array}{l}-0.0661^{\mathrm{a}} \\
(0.0324) \\
\end{array}$ \\
\hline$a_{8}$ & $\begin{array}{c}0.0383 \\
(0.0326) \\
\end{array}$ & $\begin{array}{l}-0.0268 \\
(0.0329) \\
\end{array}$ & $\begin{array}{l}-0.0403 \\
(0.0325) \\
\end{array}$ & $\begin{array}{l}-0.0115 \\
(0.0324) \\
\end{array}$ & $\begin{array}{c}-0.0014 \\
(0.0328) \\
\end{array}$ & $\begin{array}{l}-0.0793^{\mathrm{a}} \\
(0.0325) \\
\end{array}$ \\
\hline$a_{9}$ & $\begin{array}{c}0.0428 \\
(0.0326) \\
\end{array}$ & $\begin{array}{c}0.0088 \\
(0.0329) \\
\end{array}$ & $\begin{array}{c}0.0076 \\
(0.0325) \\
\end{array}$ & $\begin{array}{l}-0.0124 \\
(0.0323)\end{array}$ & $\begin{array}{c}0.0259 \\
(0.0328) \\
\end{array}$ & $\begin{array}{l}-0.0233 \\
(0.0326)\end{array}$ \\
\hline$a_{10}$ & $\begin{array}{c}0.1202^{\mathrm{a}} \\
(0.0325)\end{array}$ & $\begin{array}{c}0.0499 \\
(0.0327) \\
\end{array}$ & $\begin{array}{l}0.0696^{\mathrm{b}} \\
(0.0325)\end{array}$ & $\begin{array}{l}0.0747^{\mathrm{b}} \\
(0.0322)\end{array}$ & $\begin{array}{c}0.0170 \\
(0.0326)\end{array}$ & $\begin{array}{l}0.0650^{\mathrm{a}} \\
(0.0326) \\
\end{array}$ \\
\hline$\gamma_{1}$ & $\begin{array}{c}5.27 \cdot 10^{-4} \\
\left(5.02 \cdot 10^{-4}\right) \\
\end{array}$ & $\begin{array}{l}-0.61 \cdot 10^{-4} \\
\left(3.70 \cdot 10^{-4}\right) \\
\end{array}$ & $\begin{array}{l}-2.13 \cdot 10^{-4} \\
\left(3.51 \cdot 10^{-4}\right) \\
\end{array}$ & $\begin{array}{c}2.83 \cdot 10^{-4} \\
\left(4.85 \cdot 10^{-4}\right) \\
\end{array}$ & $\begin{array}{c}5.24 \cdot 10^{-4} \\
\left(4.68 \cdot 10^{-4}\right) \\
\end{array}$ & $\begin{array}{c}0.24 \cdot 10^{-4} \\
\left(3.57 \cdot 10^{-4}\right) \\
\end{array}$ \\
\hline$\gamma_{2}$ & $\begin{array}{c}0.42 \cdot 10^{-4} \\
\left(4.99 \cdot 10^{-4}\right) \\
\end{array}$ & $\begin{array}{c}0.21 \cdot 10^{-4} \\
\left(3.68 \cdot 10^{-4}\right) \\
\end{array}$ & $\begin{array}{c}2.30 \cdot 10^{-4} \\
\left(3.50 \cdot 10^{-4}\right) \\
\end{array}$ & $\begin{array}{l}-2.37 \cdot 10^{-4} \\
\left(4.83 \cdot 10^{-4}\right) \\
\end{array}$ & $\begin{array}{c}7.80 \cdot 10^{-4} \\
\left(4.67 \cdot 10^{-4}\right) \\
\end{array}$ & $\begin{array}{c}1.46 \cdot 10^{-4} \\
\left(3.56 \cdot 10^{-4}\right) \\
\end{array}$ \\
\hline$\gamma_{3}$ & $\begin{array}{c}8.51 \cdot 10^{-4 c} \\
\left(5.01 \cdot 10^{-4}\right) \\
\end{array}$ & $\begin{array}{c}3.62 \cdot 10^{-4} \\
\left(3.69 \cdot 10^{-4}\right) \\
\end{array}$ & $\begin{array}{c}4.92 \cdot 10^{-4} \\
\left(3.51 \cdot 10^{-4}\right) \\
\end{array}$ & $\begin{array}{l}-6.55 \cdot 10^{-4} \\
\left(4.84 \cdot 10^{-4}\right)\end{array}$ & $\begin{array}{c}7.04 \cdot 10^{-4} \\
\left(4.69 \cdot 10^{-4}\right)\end{array}$ & $\begin{array}{c}5.25 \cdot 10^{-4} \\
\left(3.57 \cdot 10^{-4}\right)\end{array}$ \\
\hline$\gamma_{4}$ & $\begin{array}{c}3.78 \cdot 10^{-4} \\
\left(4.99 \cdot 10^{-4}\right) \\
\end{array}$ & $\begin{array}{c}1.93 \cdot 10^{-4} \\
\left(3.68 \cdot 10^{-4}\right)\end{array}$ & $\begin{array}{c}3.12 \cdot 10^{-4} \\
\left(3.49 \cdot 10^{-4}\right)\end{array}$ & $\begin{array}{c}2.82 \cdot 10^{-4} \\
\left(4.83 \cdot 10^{-4}\right)\end{array}$ & $\begin{array}{c}7.26 \cdot 10^{-4} \\
\left(4.65 \cdot 10^{-4}\right)\end{array}$ & $\begin{array}{c}5.04 \cdot 10^{-4} \\
\left(3.55 \cdot 10^{-4}\right)\end{array}$ \\
\hline$\gamma_{5}$ & $\begin{array}{c}6.00 \cdot 10^{-4} \\
\left(8.06 \cdot 10^{-4}\right)\end{array}$ & $\begin{array}{c}8.23 \cdot 10^{-4} \\
\left(5.93 \cdot 10^{-4}\right)\end{array}$ & $\begin{array}{l}13.02 \cdot 10^{-4 b} \\
\left(5.63 \cdot 10^{-4}\right)\end{array}$ & $\begin{array}{c}-24.76 \cdot 10^{-4 a} \\
\left(7.78 \cdot 10^{-4}\right)\end{array}$ & $\begin{array}{l}11.32 \cdot 10^{-4} \\
\left(7.52 \cdot 10^{-4}\right)\end{array}$ & $\begin{array}{l}10.71 \cdot 10^{-4 c} \\
\left(5.72 \cdot 10^{-4}\right)\end{array}$ \\
\hline
\end{tabular}

Standard errors are in parentheses. Significantly different from zero at $1 \%\left({ }^{\mathrm{a}}\right), 5 \%\left({ }^{\mathrm{b}}\right)$, and $10 \%\left({ }^{c}\right)$ level. 
Table 5

Estimating Conditional Variance for $\operatorname{GARCH}(1,1)$

$$
\mathrm{h}_{\mathrm{t}}=\omega+\alpha \varepsilon_{\mathrm{t}-1}^{2}+\beta \mathrm{h}_{\mathrm{t}-1}+\phi_{1} \mathrm{~d}_{\mathrm{MO}, \mathrm{t}}+\phi_{2} \mathrm{~d}_{\mathrm{TU}, \mathrm{t}}+\phi_{3} \mathrm{~d}_{\mathrm{WE}, \mathrm{t}}+\phi_{4} \mathrm{~d}_{\mathrm{TH}, \mathrm{t}}+\phi_{5} \mathrm{~d}_{\mathrm{HO}, \mathrm{t}}
$$

\begin{tabular}{ccccccc}
\hline $\begin{array}{c}\text { Estimates } \\
\text { and statistics }\end{array}$ & GBP & ATS & DEM & USD & CHF & FRF \\
\hline$\omega$ & $0.036 \cdot 10^{-6}$ & $1.68 \cdot 10^{-6}$ & $1.75 \cdot 10^{-6 \mathrm{~b}}$ & $5.89 \cdot 10^{-6 \mathrm{a}}$ & $0.98 \cdot 10^{-6}$ & $0.90 \cdot 10^{-6}$ \\
& $\left(1.07 \cdot 10^{-6}\right)$ & $\left(0.95 \cdot 10^{-6}\right)$ & $\left(0.69 \cdot 10^{-6}\right)$ & $\left(1.48 \cdot 10^{-6}\right)$ & $\left(1.70 \cdot 10^{-6}\right)$ & $\left(0.77 \cdot 10^{-6}\right)$ \\
\hline$\alpha$ & $0.164^{\mathrm{a}}$ & $0.048^{\mathrm{a}}$ & $0.056^{\mathrm{a}}$ & $0.056^{\mathrm{a}}$ & $0.053^{\mathrm{a}}$ & $0.124^{\mathrm{a}}$ \\
& $(0.013)$ & $(0.013)$ & $(0.010)$ & $(0.015)$ & $(0.011)$ & $(0.016)$ \\
\hline$\beta$ & $0.824^{\mathrm{a}}$ & $0.913^{\mathrm{a}}$ & $0.922^{\mathrm{a}}$ & $0.906^{\mathrm{a}}$ & $0.934^{\mathrm{a}}$ & $0.837^{\mathrm{a}}$ \\
& $(0.016)$ & $(0.019)$ & $(0.013)$ & $(0.021)$ & $(0.013)$ & $(0.023)$ \\
\hline$\phi_{1}$ & $1.35 \cdot 10^{-6}$ & $-0.12 \cdot 10^{-6}$ & $-1.73 \cdot 10^{-6}$ & $-5.95 \cdot 10^{-6 \mathrm{~b}}$ & $-2.32 \cdot 10^{-6}$ & $0.26 \cdot 10^{-6}$ \\
& $\left(1.69 \cdot 10^{-6}\right)$ & $\left(1.54 \cdot 10^{-6}\right)$ & $\left(1.16 \cdot 10^{-6}\right)$ & $\left(2.63 \cdot 10^{-6}\right)$ & $\left(2.89 \cdot 10^{-6}\right)$ & $\left(1.38 \cdot 10^{-6}\right)$ \\
\hline$\phi_{2}$ & $1.91 \cdot 10^{-6}$ & $3.38 \cdot 10^{-6}$ & $5.81 \cdot 10^{-6 \mathrm{a}}$ & $5.31 \cdot 10^{-6 \mathrm{c}}$ & $5.88 \cdot 10^{-6 \mathrm{~b}}$ & $2.77 \cdot 10^{-6 \mathrm{~b}}$ \\
& $\left(1.56 \cdot 10^{-6}\right)$ & $\left(1.81 \cdot 10^{-6}\right)$ & $\left(1.33 \cdot 10^{-6}\right)$ & $\left(3.12 \cdot 10^{-6}\right)$ & $\left(2.82 \cdot 10^{-6}\right)$ & $\left(1.43 \cdot 10^{-6}\right)$ \\
\hline$\phi_{3}$ & $-0.94 \cdot 10^{-6}$ & $-7.98 \cdot 10^{-6 \mathrm{a}}$ & $-10.38 \cdot 10^{-6 \mathrm{a}}$ & $-19.03 \cdot 10^{-6 \mathrm{a}}$ & $-8.33 \cdot 10^{-6 \mathrm{a}}$ & $-5.90 \cdot 10^{-6 \mathrm{a}}$ \\
& $\left(1.60 \cdot 10^{-6}\right)$ & $\left(1.47 \cdot 10^{-6}\right)$ & $\left(1.25 \cdot 10^{-6}\right)$ & $\left(2.86 \cdot 10^{-6}\right)$ & $\left(2.72 \cdot 10^{-6}\right)$ & $\left(1.24 \cdot 10^{-6}\right)$ \\
\hline$\phi_{4}$ & $-0.02 \cdot 10^{-6}$ & $-1.65 \cdot 10^{-6}$ & $-1.19 \cdot 10^{-6}$ & $-5.87 \cdot 10^{-6 \mathrm{a}}$ & $0.75 \cdot 10^{-6}$ & $0.44 \cdot 10^{-6}$ \\
& $\left(2.04 \cdot 10^{-6}\right)$ & $\left(1.82 \cdot 10^{-6}\right)$ & $\left(1.14 \cdot 10^{-6}\right)$ & $\left(2.26 \cdot 10^{-6}\right)$ & $\left(2.62 \cdot 10^{-6}\right)$ & $\left(1.19 \cdot 10^{-6}\right)$ \\
\hline$\phi_{5}$ & $3.45 \cdot 10^{-6}$ & $2.75 \cdot 10^{-6}$ & $0.47 \cdot 10^{-6}$ & $2.64 \cdot 10^{-6}$ & $3.71 \cdot 10^{-6 \mathrm{~b}}$ & $2.76 \cdot 10^{-6}$ \\
& $\left(2.14 \cdot 10^{-6}\right)$ & $\left(1.31 \cdot 10^{-6}\right)$ & $\left(0.68 \cdot 10^{-6}\right)$ & $\left(2.02 \cdot 10^{-6}\right)$ & $\left(1.79 \cdot 10^{-6}\right)$ & $\left(1.70 \cdot 10^{-6}\right)$ \\
\hline
\end{tabular}

Standard errors are in parentheses. Significantly different from zero at $1 \%\left({ }^{a}\right), 5 \%\left({ }^{b}\right)$, and $10 \%\left(^{c}\right)$ level.

Table 6

Tests on Standardized Residuals

\begin{tabular}{ccccccc}
\hline Statistics & GBP & ATS & DEM & USD & CHF & FRF \\
\hline Mean & 0.006 & 0.008 & 0.016 & 0.003 & 0.009 & 0.006 \\
\hline Variance & 1.117 & 1.012 & 1.056 & 1.129 & 1.004 & 1.004 \\
\hline Skewness & -1.284 & -0.212 & 0.017 & 1.370 & 0.031 & -0.547 \\
\hline Kurtosis & 12.795 & 1.028 & 3.200 & 12.436 & 0.885 & 1.772 \\
\hline $\mathrm{nQ}(10)$ & 8.427 & 2.443 & 2.522 & 2.918 & 1.572 & 4.411 \\
\hline $\mathrm{nQ}^{2}(10)$ & 1.637 & 20.826 & 4.246 & 6.152 & 11.850 & 19.144 \\
\hline
\end{tabular}

Ljung-Box: critical value of 23.21 from $\chi^{2}$ distribution with 10 d.f. at $1 \%$ level is used. 
Table 7

BDS Test: First Logarithmic Differences

\begin{tabular}{|c|c|c|c|c|c|c|c|}
\hline m & $\varepsilon$ & ATS & GBP & DEM & USD & $\mathrm{CHF}$ & FRF \\
\hline 2 & 1 & $8.72 *$ & $7.86^{*}$ & $3.70^{*}$ & 1.19 & $3.64^{*}$ & $4.72 *$ \\
\hline 3 & 1 & $10.3^{*}$ & $10.2 *$ & $4.11^{*}$ & 1.09 & $4.18^{*}$ & $5.68 *$ \\
\hline 4 & 1 & $11.7^{*}$ & $12.0^{*}$ & $4.90 *$ & 1.62 & $4.88^{*}$ & $6.93 *$ \\
\hline 5 & 1 & $12.7 *$ & $13.27 *$ & $5.62 *$ & $2.34 *$ & $5.74 *$ & $8.12 *$ \\
\hline 6 & 1 & $14.21 *$ & $14.39^{*}$ & $6.43 *$ & $3.19^{*}$ & $6.46^{*}$ & $9.57 *$ \\
\hline 7 & 1 & $16.25^{*}$ & $15.28^{*}$ & $7.30 *$ & $3.89^{*}$ & $6.92 *$ & $11.36^{*}$ \\
\hline 8 & 1 & $18.50^{*}$ & $16.23^{*}$ & $8.06^{*}$ & $4.46^{*}$ & $7.28^{*}$ & $12.76^{*}$ \\
\hline 9 & 1 & $21.13^{*}$ & $17.26^{*}$ & $9.10^{*}$ & $5.06^{*}$ & $7.48^{*}$ & $14.36^{*}$ \\
\hline 10 & 1 & $24.01 *$ & $18.40^{*}$ & $10.32 *$ & $5.56^{*}$ & $7.45^{*}$ & $15.87^{*}$ \\
\hline 2 & $1 / 2$ & $2.87 *$ & $6.27 *$ & $3.69 *$ & 1.91 & $3.35^{*}$ & $7.18^{*}$ \\
\hline 3 & $1 / 2$ & $2.68^{*}$ & $7.80^{*}$ & $3.83^{*}$ & 1.74 & $4.06^{*}$ & $8.59 *$ \\
\hline 4 & $1 / 2$ & $2.39 *$ & $9.31 *$ & $4.48^{*}$ & 2.19 & $4.56^{*}$ & $10.45^{*}$ \\
\hline 5 & $1 / 2$ & 1.96 & $10.20^{*}$ & $5.03 *$ & $2.61 *$ & $4.84 *$ & $12.35^{*}$ \\
\hline 6 & $1 / 2$ & 2.18 & $10.88^{*}$ & $5.36^{*}$ & $3.31 *$ & $4.92 *$ & $15.89 *$ \\
\hline 7 & $1 / 2$ & $3.10^{*}$ & $11.28^{*}$ & $6.24 *$ & $2.65^{*}$ & $6.03^{*}$ & $21.01 *$ \\
\hline 8 & $1 / 2$ & $3.34 *$ & $11.73^{*}$ & $5.27 *$ & $3.81^{*}$ & $6.06^{*}$ & $26.91 *$ \\
\hline 9 & $1 / 2$ & $5.16^{*}$ & $12.67 *$ & $2.99 *$ & $3.19^{*}$ & $4.37 *$ & $35.85^{*}$ \\
\hline 10 & $1 / 2$ & $6.82^{*}$ & $13.43^{*}$ & 1.60 & $8.44^{*}$ & -2.66 & $50.24 *$ \\
\hline
\end{tabular}

BDS follows t-distribution. * indicates 1\% significance level (> 2.33). 
Table 8

BDS Tests of Nonlinearity: Standardized Residuals

GARCH $(1,1)$

\begin{tabular}{cccccccc}
\hline $\mathrm{m}$ & $\varepsilon$ & GBP & ATS & DEM & USD & CHF & FRF \\
\hline 2 & 1 & -1.92 & -0.51 & -1.10 & -0.84 & 0.79 & -0.53 \\
\hline 3 & 1 & $-2.02^{*}$ & -0.68 & -1.37 & -1.27 & 0.75 & -1.09 \\
\hline 4 & 1 & $-1.61^{*}$ & -0.47 & -1.37 & $-1.43^{*}$ & 0.79 & -1.23 \\
\hline 5 & 1 & $-1.78^{*}$ & -0.66 & -1.35 & $-1.50^{*}$ & 0.98 & -1.20 \\
\hline 6 & 1 & -1.88 & -0.71 & -1.40 & -1.55 & 1.07 & -1.06 \\
\hline 7 & 1 & -2.19 & -0.71 & -1.47 & -1.44 & 1.11 & -0.77 \\
\hline 8 & 1 & -2.37 & -0.71 & -1.51 & -1.32 & 0.97 & -0.92 \\
\hline 9 & 1 & -2.52 & -0.69 & -1.41 & -1.22 & 0.59 & -0.93 \\
\hline 10 & 1 & $-2.63 *$ & -0.64 & -1.46 & -1.15 & 0.23 & -0.94 \\
\hline & & & & & & & \\
\hline 2 & 0.5 & -1.95 & 0.20 & -0.51 & -1.26 & 1.01 & -0.87 \\
\hline 3 & 0.5 & $-2.09 *$ & 0.21 & -1.02 & -1.73 & 0.84 & -1.37 \\
\hline 4 & 0.5 & -1.71 & -0.01 & -0.97 & -1.80 & 0.92 & -1.38 \\
\hline 5 & 0.5 & -2.11 & -0.37 & -0.93 & -1.86 & 0.27 & -1.72 \\
\hline 6 & 0.5 & -2.09 & -0.50 & -1.80 & -2.14 & -0.69 & -1.66 \\
\hline 7 & 0.5 & -1.77 & -0.63 & -1.36 & -1.99 & -1.83 & -1.19 \\
\hline 8 & 0.5 & -1.85 & -0.57 & -1.12 & -1.20 & -3.69 & -0.69 \\
\hline 9 & 0.5 & -2.57 & 1.66 & -2.02 & -0.72 & -4.59 & -0.67 \\
\hline 10 & 0.5 & -1.14 & 4.99 & -0.60 & -1.72 & -4.48 & -2.21 \\
\hline
\end{tabular}

BDS: critical values in a form of Quantiles of BDS Statistic are provided in a separate Table 9.

Table 9

Quantiles of BDS Statistic

GARCH(1,1) Standardized Residuals 1000 Observations

\begin{tabular}{|c|c|c|c|c|c|c|}
\hline Quantile & & & $\mathrm{m}$ & & & \\
\hline & 2 & 3 & 4 & 5 & 10 & $\mathrm{~N}(0,1)$ \\
\hline \multicolumn{7}{|l|}{$\varepsilon=1.0 \sigma$} \\
\hline $1.0 \%$ & -1.97 & -1.64 & -1.42 & -1.45 & -1.66 & -2.33 \\
\hline $2.5 \%$ & -1.69 & -1.41 & -1.26 & -1.20 & -1.46 & -1.96 \\
\hline $97.5 \%$ & 1.63 & 1.42 & 1.32 & 1.23 & 1.75 & 1.96 \\
\hline $99.0 \%$ & 2.01 & 1.78 & 1.61 & 1.51 & 2.23 & 2.33 \\
\hline \multicolumn{7}{|l|}{$\varepsilon=0.5 \sigma$} \\
\hline $1.0 \%$ & -2.11 & -1.96 & -2.09 & -2.45 & -7.31 & -2.33 \\
\hline $2.5 \%$ & -1.84 & -1.72 & -1.80 & -2.05 & -6.93 & -1.96 \\
\hline $97.5 \%$ & 1.80 & 1.79 & 1.92 & 2.19 & 16.83 & 1.96 \\
\hline $99.0 \%$ & 2.29 & 2.18 & 2.25 & 2.69 & 23.48 & 2.33 \\
\hline
\end{tabular}

Based on 2000 replications. Source: Brock, Hsieh, and LeBaron (1993), p. 278 
Figure 1

Evolution of Exchange Rates: Nominal Levels
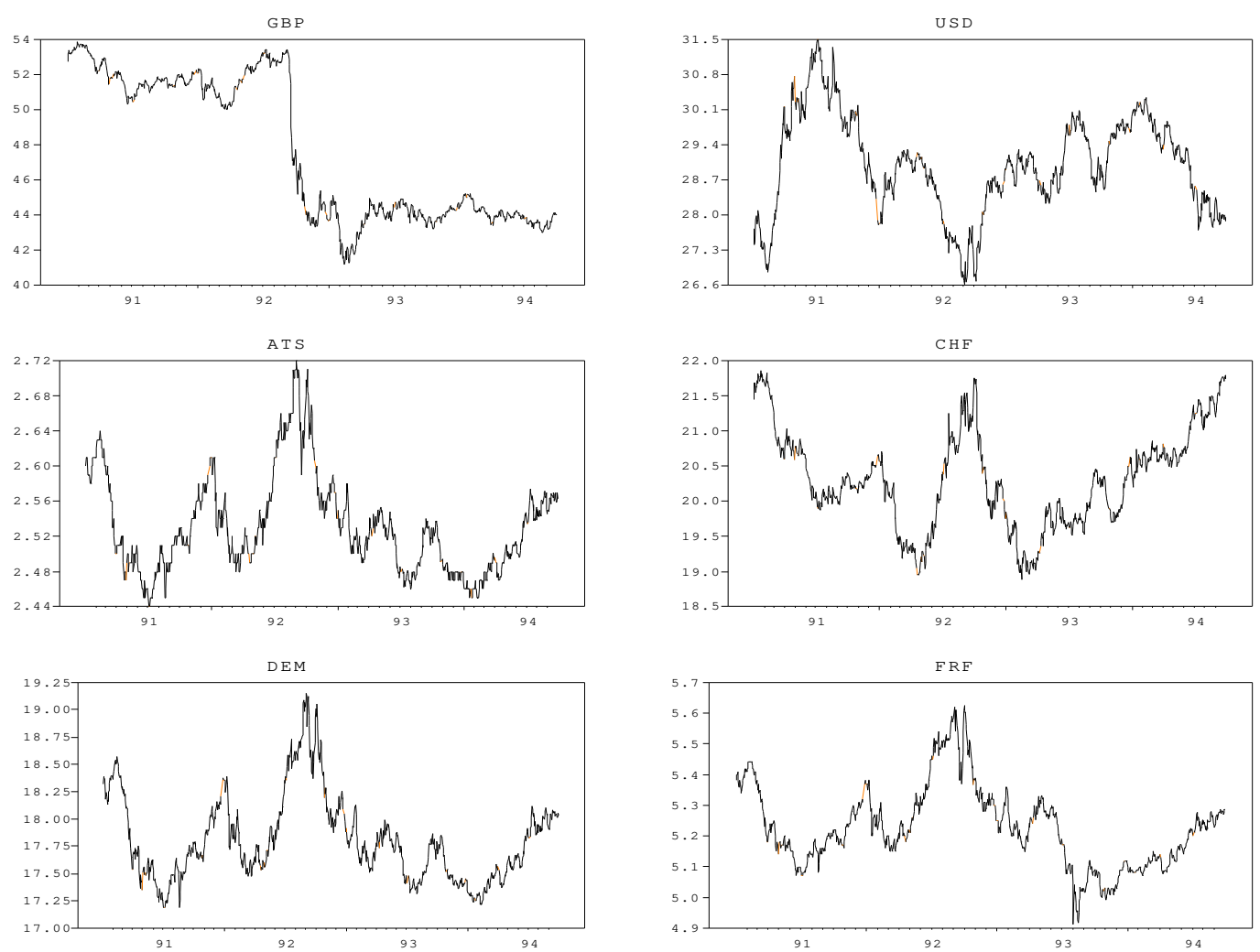
Figure 2

First Logarithmic Differences of Exchange Rates
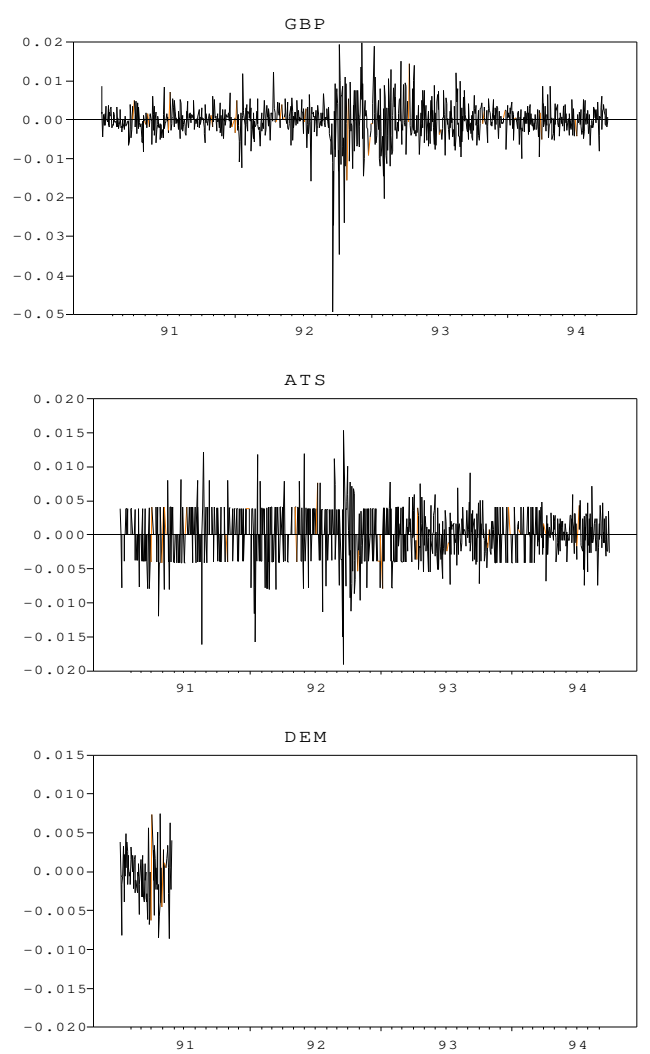
Figure 3

Evolution of the Currency Basket Index

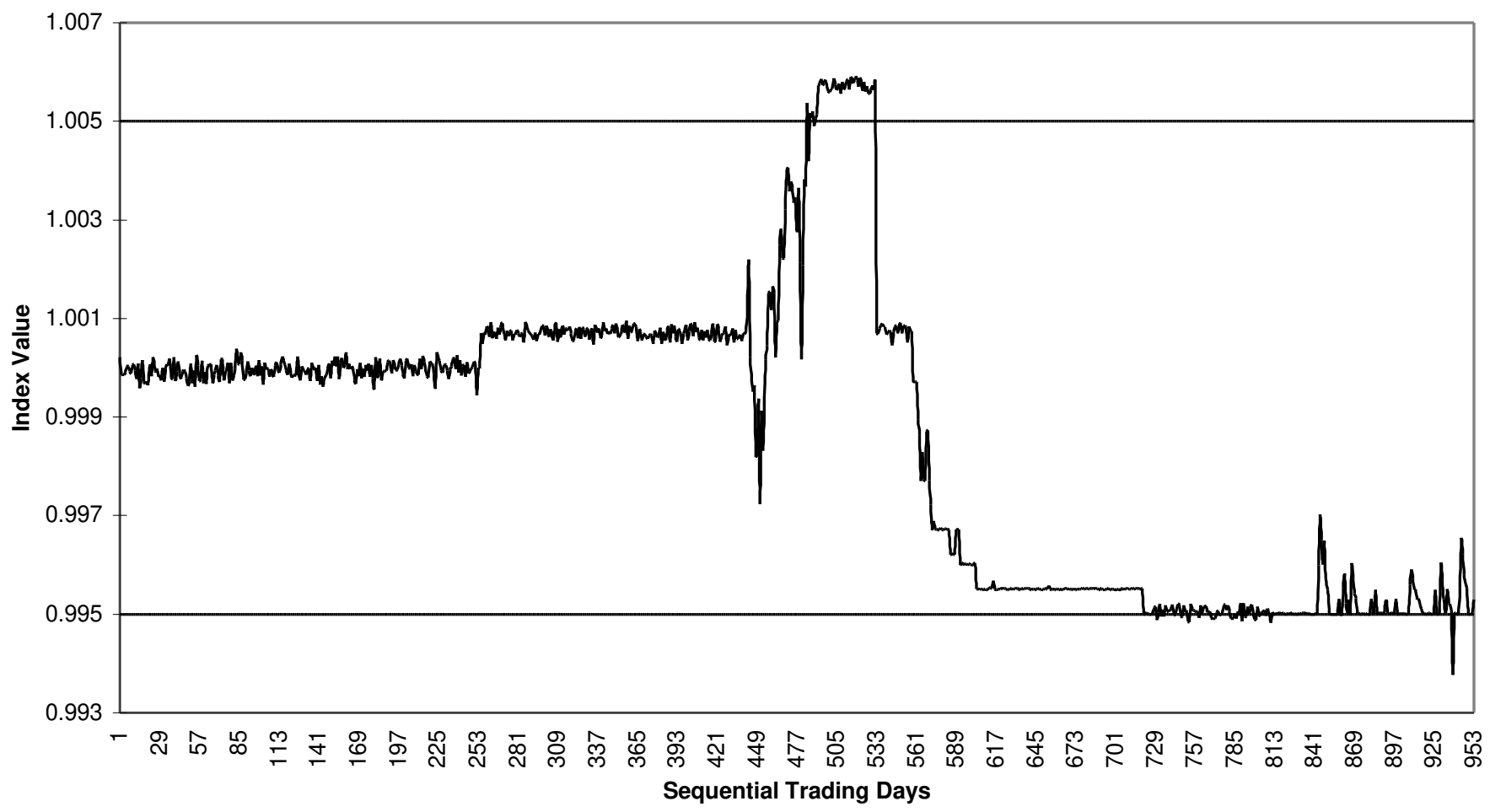





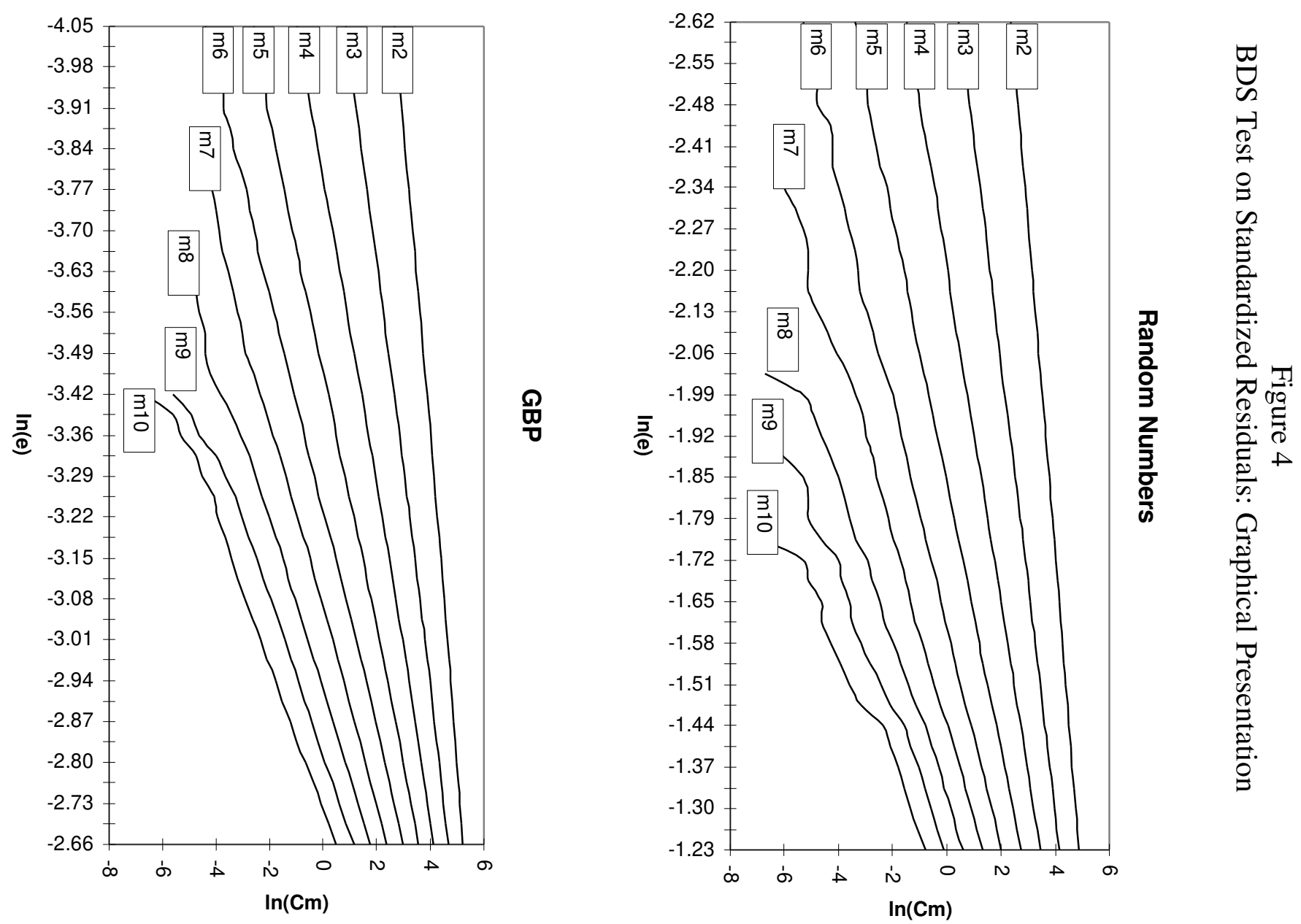

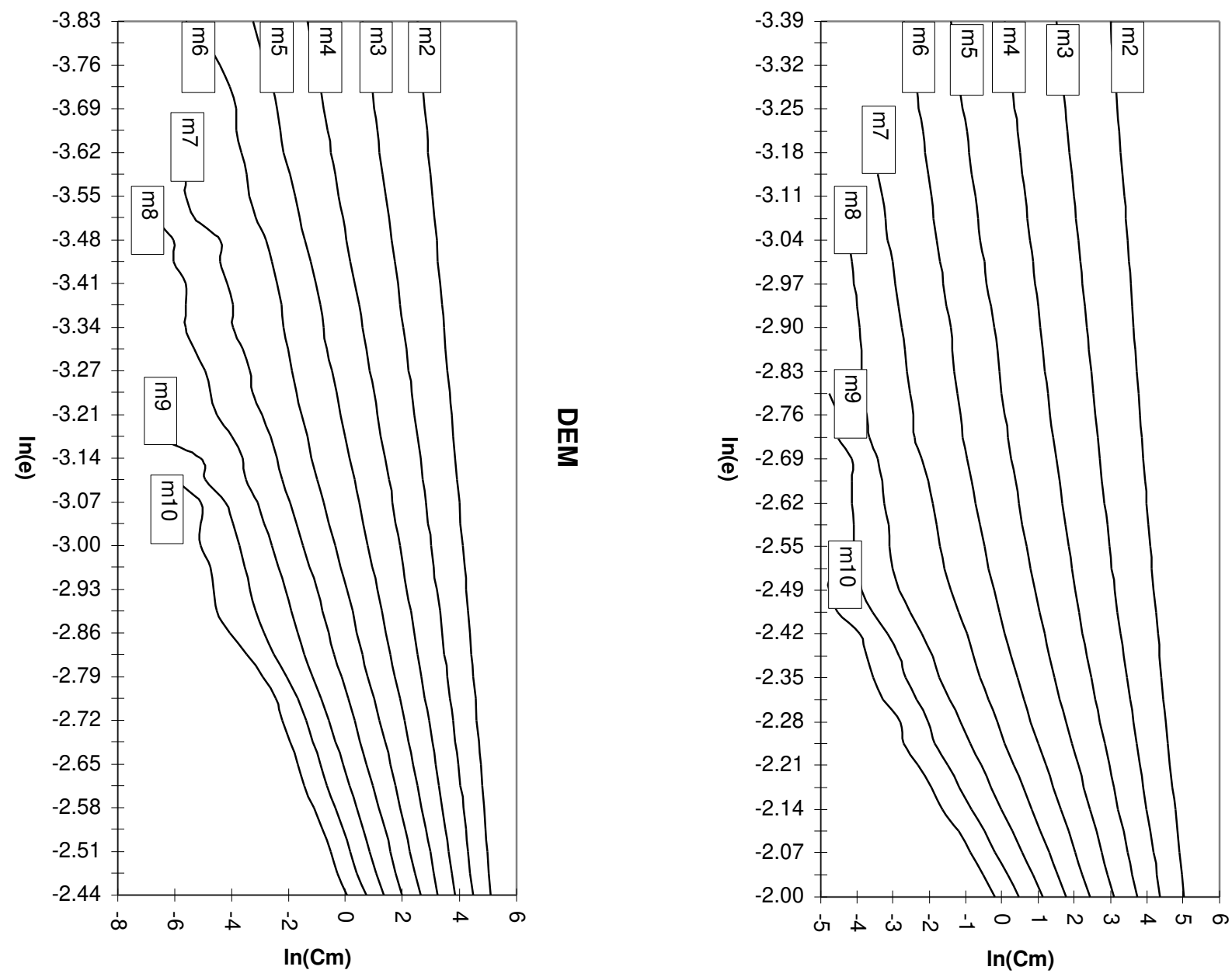

$\frac{7}{\omega}$ 

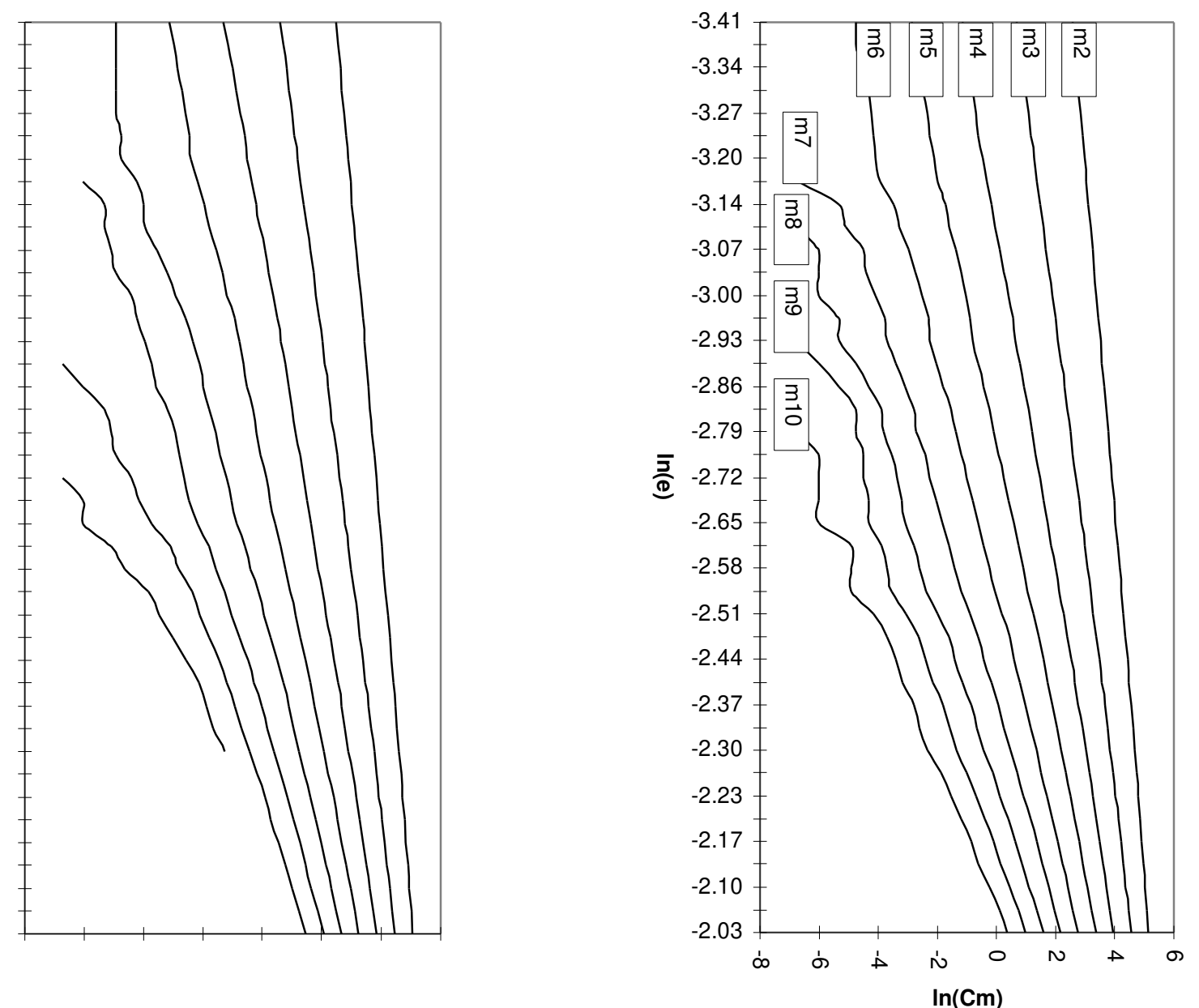

ธุ 


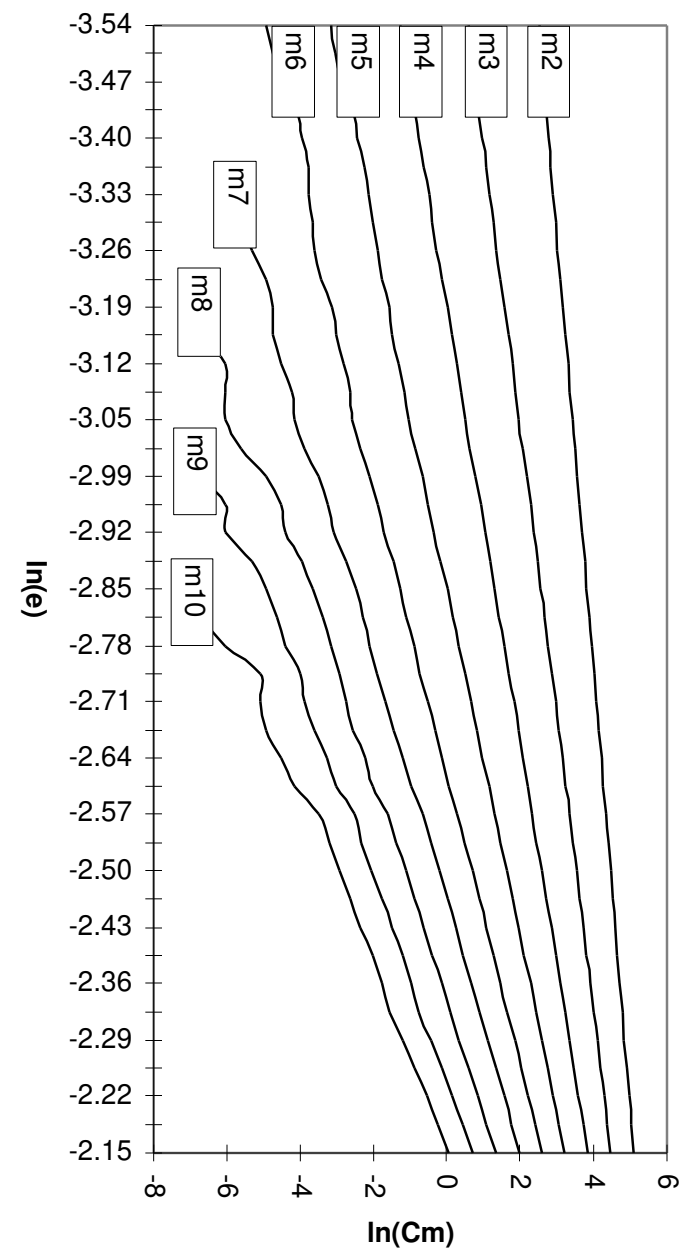

鿄 


\section{REFERENCES}

Akaike, H. 1974. "A New Look at the Statistical Model Identification," IEEE Transactions on Automatic Control 19: 716-723.

Baillie, R. T., and T. Bollerslev. 1989. "The Message in Daily Exchange Rates:A Conditional Variance Tale," Journal of Business and Economic Statistics 7: 297-305.

Berndt, E. K., B. H. Hall, R. E. Hall, and J. A. Hausman. 1974. "Estimation of Inference in Nonlinear Structural Models," Annals of Economic and Social Measurement 4: 653-665.

Bollerslev, T. 1986. "Generalized Autoregressive Conditional Heteroskedasticity," Journal of Econometrics 31: 307-327.

Bollerslev, T., and R. F. Engle. 1993. "Common Persistence in ConditionalVariances," Econometrica 61: 167-186.

Brock, W., and W. Dechert. 1988. "A General Class of Specification Tests: The Scalar Case," in the Business and Economics Statistics Section of the Proceeding of the American Statistical Society: 70-79.

Brock, W., W. Dechert, and J. Scheinkman. 1987. "A Test for Independence Based on the Correlation Dimension," University of Wisconsin at Madison, Department of Economics Working Paper.

Brock, W., W. Dechert, J. Scheinkman, and B. LeBaron. 1994. "A Test for Independence Based on the Correlation Dimension," forthcoming in Econometric Reviews.

Brock, W. A., D. A. Hsieh, and B. LeBaron. 1993. "Nonlinear Dynamics, Chaos, and Instability: Statistical Theory and Economic Evidence," The MIT Press, Cambridge, MA.

Dechert, W. D. 1987. "A Program to Calculate BDS Statistics for the IBM PC," Department of Economics, University of Houston.

Engle, R. F. 1982. "Autoregressive Conditional Heteroskedasticity with Estimates of the Variance of United Kingdom Inflation," Econometrica 50: 987-1007.

Friedman, D., and S. Vandersteel. 1982. "Short-Run Fluctuations in Foreign Exchange Rates," Journal of International Economics 13: 171-186.

Grassberger, P., and I. Procaccia. 1983. "Measuring the Strangeness of Strange Attractors," Physica 9D: 189-208.

Hsieh, D. A. 1988. "Statistical Properties of Daily Exchange Rates: 19741983," Journal of International Economics 24: 129-145.

-1989. "Testing for Nonlinear Dependence in Daily Foreign Exchange Rates," Journal of Business 62: 339-368.

.1991. "Chaos and Nonlinear Dynamics: Application to Financial Markets," Journal of Finance 46: 1839-1877.

Ljung, G. M., and G. E. P. Box. 1978. "On a Measure of Lack of Fit in Time Series Models,” Biometrika 65: 297-303. 
Mandelbrot, B. 1963. "The Variation of Certain Speculative Prices," Journal of Business 36: 394-419.

Milhøj, A. 1987. "A Conditional Variance Model for Daily Deviations of an Exchange Rate," Journal of Business and Economic Statistics 5: 99-103.

Nelson, D. A. 1991. "Conditional Heteroskedasticity in Asset Returns: A New Approach," Econometrica 59: 347-370.

Svensson, L. E. O. 1994. "Fixed Exchange Rates as a Means to Price Stability: What Have We Learned?" European Economic Review 38: 447-468. 


\section{TABLES}

Table 1

Summary Statistics of Log Price Changes:

$$
\mathrm{r}_{\mathrm{t}}=\log \left(\mathrm{R}_{\mathrm{t}} / \mathrm{R}_{\mathrm{t}-1}\right)^{*} 100
$$

\begin{tabular}{ccccccc}
\hline Statistics & GBP & ATS & DEM & USD & CHF & FRF \\
\hline Mean & -0.02163 & -0.00242 & -0.00416 & 0.00534 & -0.00156 & -0.00447 \\
\hline Variance & 0.23785 & 0.12908 & 0.11577 & 0.22176 & 0.20454 & 0.12005 \\
\hline Skewness & -1.68703 & -0.40586 & -0.57688 & 0.34574 & -0.16915 & -0.76434 \\
\hline Kurtosis & 16.2077 & 2.35196 & 3.21914 & 1.65811 & 2.57694 & 6.27226 \\
\hline Maximum & 1.99089 & 1.53259 & 1.28961 & 2.45490 & 2.28472 & 1.49497 \\
\hline Minimum & -4.9373 & -1.19121 & -1.73237 & -1.69109 & -2.34774 & -2.75034 \\
\hline
\end{tabular}

Table 2

Basket Composition, Currency Weights, and Base Rates across Periods

\begin{tabular}{cccccccc}
\hline Period & & GBP & ATS & DEM & USD & CHF & FRF \\
\hline Jan. 1,1991-Jan. 1, 1992 & Weight & 0.0424 & 0.1235 & 0.4552 & 0.3134 & 0.0655 & - \\
\hline & Base Rate & 52.50 & 2.59 & 18.23 & 28.00 & 21.34 & - \\
\hline Jan. 2, 1992-May 2, 1993 & Weight & - & 0.0807 & 0.3615 & 0.4907 & 0.0379 & 0.0292 \\
\hline & Base Rate & - & 2.61 & 18.35 & 27.84 & 20.57 & 5.37 \\
\hline May 3, 1993-Sep. 30, & Weight & - & - & 0.6500 & 0.3500 & - & - \\
1994 & & & & & & & - \\
\hline & Base Rate & - & - & 17.995 & 28.443 & - & - \\
\hline
\end{tabular}

Weights add up to 1 and represent the relative importance of a particular currency in the balance of payments. Base rates are constant over the respective period.

Table 3

Testing for Conditional Heteroskedasticity and Serial Correlation

\begin{tabular}{ccccccc}
\hline Statistics & GBP & ATS & DEM & USD & CHF & FRF \\
\hline LM $(10)$ & 77.00 & 114.44 & 82.34 & 51.06 & 77.49 & 96.01 \\
\hline $\mathrm{Q}(10)$ & 0.3536 & 0.0964 & 0.0936 & 0.282 & 0.0104 & 0.1987 \\
\hline $\mathrm{Q}^{2}(10)$ & 110.05 & 156.94 & 130.32 & 64.97 & 94.24 & 135.09 \\
\hline Skewness & -1.441 & -0.404 & -0.674 & 0.326 & -0.179 & -0.854 \\
\hline Kurtosis & 14.600 & 2.394 & 3.523 & 1.815 & 2.561 & 6.474 \\
\hline
\end{tabular}

LM: Lagrange-multiplier test by Engle (1982), Q: Ljung-box test against higher order serial correlation by Ljung-Box (1978), $\chi^{2}$ critical value at $1 \%$ level with 10 d.f. is 23.21 
Table 4

Estimating the Mean Equation for $\operatorname{GARCH}(1,1)$

$$
\mathrm{r}_{\mathrm{t}}=\mathrm{a}_{0}+\sum_{\mathrm{i}=1}^{10} \mathrm{a}_{\mathrm{i}} \mathrm{r}_{\mathrm{t}-10}+\sum_{\mathrm{j}=1}^{5} \gamma_{\mathrm{j}} \mathrm{d}_{\mathrm{jt}}+\varepsilon_{\mathrm{t}}
$$

\begin{tabular}{|c|c|c|c|c|c|c|}
\hline $\begin{array}{c}\text { Estimates and } \\
\text { statistics }\end{array}$ & GBP & ATS & DEM & USD & $\mathrm{CHF}$ & FRF \\
\hline $\mathrm{a}_{0}$ & $\begin{array}{l}-0.000529 \\
(0.000355)\end{array}$ & $\begin{array}{l}-0.000123 \\
(0.000261)\end{array}$ & $\begin{array}{l}-0.000208 \\
(0.000248)\end{array}$ & $\begin{array}{l}-0.000243 \\
(0.000343)\end{array}$ & $\begin{array}{c}-0.000581 \\
(0.000331)\end{array}$ & $\begin{array}{l}-0.000284 \\
(0.000252)\end{array}$ \\
\hline$a_{1}$ & $\begin{array}{c}0.0270 \\
(0.0326)\end{array}$ & $\begin{array}{l}-0.1070^{\mathrm{a}} \\
(0.0328)\end{array}$ & $\begin{array}{l}-0.0446 \\
(0.0327)\end{array}$ & $\begin{array}{c}-0.0155 \\
(0.0326)\end{array}$ & $\begin{array}{l}-0.0564 \\
(0.0329)\end{array}$ & $\begin{array}{c}0.0024 \\
(0.0327)\end{array}$ \\
\hline$a_{2}$ & $\begin{array}{c}0.0569^{c} \\
(0.0326)\end{array}$ & $\begin{array}{l}-0.0271 \\
(0.0330)\end{array}$ & $\begin{array}{c}0.0304 \\
(0.0337) \\
\end{array}$ & $\begin{array}{c}0.0460 \\
(0.0326)\end{array}$ & $\begin{array}{l}-0.0190 \\
(0.0328)\end{array}$ & $\begin{array}{l}-0.0217 \\
(0.0327)\end{array}$ \\
\hline$a_{3}$ & $\begin{array}{c}0.0302 \\
(0.0326) \\
\end{array}$ & $\begin{array}{c}0.0489 \\
(0.0330) \\
\end{array}$ & $\begin{array}{l}-0.0227 \\
(0.0327)\end{array}$ & $\begin{array}{l}-0.0154 \\
(0.0326)\end{array}$ & $\begin{array}{l}-0.0307 \\
(0.0328)\end{array}$ & $\begin{array}{c}0.0122 \\
(0.0326) \\
\end{array}$ \\
\hline$a_{4}$ & $\begin{array}{c}0.0451 \\
(0.0326) \\
\end{array}$ & $\begin{array}{c}0.0397 \\
(0.0330) \\
\end{array}$ & $\begin{array}{c}0.0592 \\
(0.0326) \\
\end{array}$ & $\begin{array}{c}0.0448 \\
(0.0325) \\
\end{array}$ & $\begin{array}{c}0.0466 \\
(0.0328) \\
\end{array}$ & $\begin{array}{c}0.0517 \\
(0.0325) \\
\end{array}$ \\
\hline$a_{5}$ & $\begin{array}{l}-0.0400 \\
(0.0327) \\
\end{array}$ & $\begin{array}{c}0.0214 \\
(0.0330) \\
\end{array}$ & $\begin{array}{c}0.0283 \\
(0.0327) \\
\end{array}$ & $\begin{array}{c}0.0151 \\
(0.0326) \\
\end{array}$ & $\begin{array}{c}0.0018 \\
(0.0328) \\
\end{array}$ & $\begin{array}{c}0.0214 \\
(0.0325)\end{array}$ \\
\hline$a_{6}$ & $\begin{array}{l}-0.0165 \\
(0.0326)\end{array}$ & $\begin{array}{l}-0.0533 \\
(0.0330)\end{array}$ & $\begin{array}{l}-0.0551 \\
(0.0327)\end{array}$ & $\begin{array}{l}-0.0421 \\
(0.0326)\end{array}$ & $\begin{array}{l}-0.0130 \\
(0.0328)\end{array}$ & $\begin{array}{l}-0.0233 \\
(0.0325)\end{array}$ \\
\hline$a_{7}$ & $\begin{array}{l}-0.0536 \\
(0.0325) \\
\end{array}$ & $\begin{array}{l}-0.0183 \\
(0.0329) \\
\end{array}$ & $\begin{array}{l}-0.0188 \\
(0.0325) \\
\end{array}$ & $\begin{array}{l}-0.0001 \\
(0.0323) \\
\end{array}$ & $\begin{array}{c}0.0232 \\
(0.0328) \\
\end{array}$ & $\begin{array}{l}-0.0661^{\mathrm{a}} \\
(0.0324) \\
\end{array}$ \\
\hline$a_{8}$ & $\begin{array}{c}0.0383 \\
(0.0326) \\
\end{array}$ & $\begin{array}{l}-0.0268 \\
(0.0329) \\
\end{array}$ & $\begin{array}{l}-0.0403 \\
(0.0325) \\
\end{array}$ & $\begin{array}{l}-0.0115 \\
(0.0324) \\
\end{array}$ & $\begin{array}{l}-0.0014 \\
(0.0328) \\
\end{array}$ & $\begin{array}{l}-0.0793^{\mathrm{a}} \\
(0.0325) \\
\end{array}$ \\
\hline $\mathrm{a}_{9}$ & $\begin{array}{c}0.0428 \\
(0.0326) \\
\end{array}$ & $\begin{array}{c}0.0088 \\
(0.0329) \\
\end{array}$ & $\begin{array}{c}0.0076 \\
(0.0325) \\
\end{array}$ & $\begin{array}{l}-0.0124 \\
(0.0323)\end{array}$ & $\begin{array}{c}0.0259 \\
(0.0328) \\
\end{array}$ & $\begin{array}{l}-0.0233 \\
(0.0326)\end{array}$ \\
\hline$a_{10}$ & $\begin{array}{l}0.1202^{\mathrm{a}} \\
(0.0325)\end{array}$ & $\begin{array}{c}0.0499 \\
(0.0327) \\
\end{array}$ & $\begin{array}{l}0.0696^{\mathrm{b}} \\
(0.0325)\end{array}$ & $\begin{array}{l}0.0747^{\mathrm{b}} \\
(0.0322)\end{array}$ & $\begin{array}{c}0.0170 \\
(0.0326) \\
\end{array}$ & $\begin{array}{l}0.0650^{\mathrm{a}} \\
(0.0326)\end{array}$ \\
\hline$\gamma_{1}$ & $\begin{array}{c}5.27 \cdot 10^{-4} \\
\left(5.02 \cdot 10^{-4}\right) \\
\end{array}$ & $\begin{array}{l}-0.61 \cdot 10^{-4} \\
\left(3.70 \cdot 10^{-4}\right)\end{array}$ & $\begin{array}{l}-2.13 \cdot 10^{-4} \\
\left(3.51 \cdot 10^{-4}\right) \\
\end{array}$ & $\begin{array}{c}2.83 \cdot 10^{-4} \\
\left(4.85 \cdot 10^{-4}\right) \\
\end{array}$ & $\begin{array}{c}5.24 \cdot 10^{-4} \\
\left(4.68 \cdot 10^{-4}\right) \\
\end{array}$ & $\begin{array}{c}0.24 \cdot 10^{-4} \\
\left(3.57 \cdot 10^{-4}\right) \\
\end{array}$ \\
\hline$\gamma_{2}$ & $\begin{array}{c}0.42 \cdot 10^{-4} \\
\left(4.99 \cdot 10^{-4}\right) \\
\end{array}$ & $\begin{array}{c}0.21 \cdot 10^{-4} \\
\left(3.68 \cdot 10^{-4}\right) \\
\end{array}$ & $\begin{array}{c}2.30 \cdot 10^{-4} \\
\left(3.50 \cdot 10^{-4}\right) \\
\end{array}$ & $\begin{array}{l}-2.37 \cdot 10^{-4} \\
\left(4.83 \cdot 10^{-4}\right) \\
\end{array}$ & $\begin{array}{c}7.80 \cdot 10^{-4} \\
\left(4.67 \cdot 10^{-4}\right) \\
\end{array}$ & $\begin{array}{c}1.46 \cdot 10^{-4} \\
\left(3.56 \cdot 10^{-4}\right) \\
\end{array}$ \\
\hline$\gamma_{3}$ & $\begin{array}{l}8.51 \cdot 10^{-4 c} \\
\left(5.01 \cdot 10^{-4}\right) \\
\end{array}$ & $\begin{array}{c}3.62 \cdot 10^{-4} \\
\left(3.69 \cdot 10^{-4}\right) \\
\end{array}$ & $\begin{array}{c}4.92 \cdot 10^{-4} \\
\left(3.51 \cdot 10^{-4}\right) \\
\end{array}$ & $\begin{array}{l}-6.55 \cdot 10^{-4} \\
\left(4.84 \cdot 10^{-4}\right) \\
\end{array}$ & $\begin{array}{c}7.04 \cdot 10^{-4} \\
\left(4.69 \cdot 10^{-4}\right) \\
\end{array}$ & $\begin{array}{c}5.25 \cdot 10^{-4} \\
\left(3.57 \cdot 10^{-4}\right) \\
\end{array}$ \\
\hline$\gamma_{4}$ & $\begin{array}{c}3.78 \cdot 10^{-4} \\
\left(4.99 \cdot 10^{-4}\right) \\
\end{array}$ & $\begin{array}{c}1.93 \cdot 10^{-4} \\
\left(3.68 \cdot 10^{-4}\right) \\
\end{array}$ & $\begin{array}{c}3.12 \cdot 10^{-4} \\
\left(3.49 \cdot 10^{-4}\right) \\
\end{array}$ & $\begin{array}{c}2.82 \cdot 10^{-4} \\
\left(4.83 \cdot 10^{-4}\right) \\
\end{array}$ & $\begin{array}{c}7.26 \cdot 10^{-4} \\
\left(4.65 \cdot 10^{-4}\right) \\
\end{array}$ & $\begin{array}{c}5.04 \cdot 10^{-4} \\
\left(3.55 \cdot 10^{-4}\right) \\
\end{array}$ \\
\hline$\gamma_{5}$ & $\begin{array}{c}6.00 \cdot 10^{-4} \\
\left(8.06 \cdot 10^{-4}\right)\end{array}$ & $\begin{array}{c}8.23 \cdot 10^{-4} \\
\left(5.93 \cdot 10^{-4}\right)\end{array}$ & $\begin{array}{l}13.02 \cdot 10^{-4 b} \\
\left(5.63 \cdot 10^{-4}\right)\end{array}$ & $\begin{array}{l}-24.76 \cdot 10^{-4 a} \\
\left(7.78 \cdot 10^{-4}\right)\end{array}$ & $\begin{array}{l}11.32 \cdot 10^{-4} \\
\left(7.52 \cdot 10^{-4}\right)\end{array}$ & $\begin{array}{l}10.71 \cdot 10^{-4 c} \\
\left(5.72 \cdot 10^{-4}\right)\end{array}$ \\
\hline
\end{tabular}

Standard errors are in parentheses. Significantly different from zero at $1 \%\left({ }^{\mathrm{a}}\right), 5 \%\left({ }^{\mathrm{b}}\right)$, and $10 \%\left({ }^{c}\right)$ level. 
Table 5

Estimating Conditional Variance for $\operatorname{GARCH}(1,1)$

$$
\mathrm{h}_{\mathrm{t}}=\omega+\alpha \epsilon_{\mathrm{t}-1}^{2}+\beta \mathrm{h}_{\mathrm{t}-1}+\phi_{1} \mathrm{~d}_{\mathrm{MO}, \mathrm{t}}+\phi_{2} \mathrm{~d}_{\mathrm{TU}, \mathrm{t}}+\phi_{3} \mathrm{~d}_{\mathrm{WE}, \mathrm{t}}+\phi_{4} \mathrm{~d}_{\mathrm{TH}, \mathrm{t}}+\phi_{5} \mathrm{~d}_{\mathrm{HO}, \mathrm{t}}
$$

\begin{tabular}{ccccccc}
\hline $\begin{array}{c}\text { Estimates } \\
\text { and statistics }\end{array}$ & GBP & ATS & DEM & USD & CHF & FRF \\
\hline$\omega$ & $0.036 \cdot 10^{-6}$ & $1.68 \cdot 10^{-6}$ & $1.75 \cdot 10^{-6 \mathrm{~b}}$ & $5.89 \cdot 10^{-6 \mathrm{a}}$ & $0.98 \cdot 10^{-6}$ & $0.90 \cdot 10^{-6}$ \\
& $\left(1.07 \cdot 10^{-6}\right)$ & $\left(0.95 \cdot 10^{-6}\right)$ & $\left(0.69 \cdot 10^{-6}\right)$ & $\left(1.48 \cdot 10^{-6}\right)$ & $\left(1.70 \cdot 10^{-6}\right)$ & $\left(0.77 \cdot 10^{-6}\right)$ \\
\hline$\alpha$ & $0.164^{\mathrm{a}}$ & $0.048^{\mathrm{a}}$ & $0.056^{\mathrm{a}}$ & $0.056^{\mathrm{a}}$ & $0.053^{\mathrm{a}}$ & $0.124^{\mathrm{a}}$ \\
& $(0.013)$ & $(0.013)$ & $(0.010)$ & $(0.015)$ & $(0.011)$ & $(0.016)$ \\
\hline$\beta$ & $0.824^{\mathrm{a}}$ & $0.913^{\mathrm{a}}$ & $0.922^{\mathrm{a}}$ & $0.906^{\mathrm{a}}$ & $0.934^{\mathrm{a}}$ & $0.837^{\mathrm{a}}$ \\
& $(0.016)$ & $(0.019)$ & $(0.013)$ & $(0.021)$ & $(0.013)$ & $(0.023)$ \\
\hline$\phi_{1}$ & $1.35 \cdot 10^{-6}$ & $-0.12 \cdot 10^{-6}$ & $-1.73 \cdot 10^{-6}$ & $-5.95 \cdot 10^{-6 \mathrm{~b}}$ & $-2.32 \cdot 10^{-6}$ & $0.26 \cdot 10^{-6}$ \\
& $\left(1.69 \cdot 10^{-6}\right)$ & $\left(1.54 \cdot 10^{-6}\right)$ & $\left(1.16 \cdot 10^{-6}\right)$ & $\left(2.63 \cdot 10^{-6}\right)$ & $\left(2.89 \cdot 10^{-6}\right)$ & $\left(1.38 \cdot 10^{-6}\right)$ \\
\hline$\phi_{2}$ & $1.91 \cdot 10^{-6}$ & $3.38 \cdot 10^{-6}$ & $5.81 \cdot 10^{-6 \mathrm{a}}$ & $5.31 \cdot 10^{-6 \mathrm{c}}$ & $5.88 \cdot 10^{-6 \mathrm{~b}}$ & $2.77 \cdot 10^{-6 \mathrm{~b}}$ \\
& $\left(1.56 \cdot 10^{-6}\right)$ & $\left(1.81 \cdot 10^{-6}\right)$ & $\left(1.33 \cdot 10^{-6}\right)$ & $\left(3.12 \cdot 10^{-6}\right)$ & $\left(2.82 \cdot 10^{-6}\right)$ & $\left(1.43 \cdot 10^{-6}\right)$ \\
\hline$\phi_{3}$ & $-0.94 \cdot 10^{-6}$ & $-7.98 \cdot 10^{-6 \mathrm{a}}$ & $-10.38 \cdot 10^{-6 \mathrm{a}}$ & $-19.03 \cdot 10^{-6 \mathrm{a}}$ & $-8.33 \cdot 10^{-6 \mathrm{a}}$ & $-5.90 \cdot 10^{-6 \mathrm{a}}$ \\
& $\left(1.60 \cdot 10^{-6}\right)$ & $\left(1.47 \cdot 10^{-6}\right)$ & $\left(1.25 \cdot 10^{-6}\right)$ & $\left(2.86 \cdot 10^{-6}\right)$ & $\left(2.72 \cdot 10^{-6}\right)$ & $\left(1.24 \cdot 10^{-6}\right)$ \\
\hline$\phi_{4}$ & $-0.02 \cdot 10^{-6}$ & $-1.65 \cdot 10^{-6}$ & $-1.19 \cdot 10^{-6}$ & $-5.87 \cdot 10^{-6 \mathrm{a}}$ & $0.75 \cdot 10^{-6}$ & $0.44 \cdot 10^{-6}$ \\
& $\left(2.04 \cdot 10^{-6}\right)$ & $\left(1.82 \cdot 10^{-6}\right)$ & $\left(1.14 \cdot 10^{-6}\right)$ & $\left(2.26 \cdot 10^{-6}\right)$ & $\left(2.62 \cdot 10^{-6}\right)$ & $\left(1.19 \cdot 10^{-6}\right)$ \\
\hline$\phi_{5}$ & $3.45 \cdot 10^{-6}$ & $2.75 \cdot 10^{-6}$ & $0.47 \cdot 10^{-6}$ & $2.64 \cdot 10^{-6}$ & $3.71 \cdot 10^{-6 \mathrm{~b}}$ & $2.76 \cdot 10^{-6}$ \\
& $\left(2.14 \cdot 10^{-6}\right)$ & $\left(1.31 \cdot 10^{-6}\right)$ & $\left(0.68 \cdot 10^{-6}\right)$ & $\left(2.02 \cdot 10^{-6}\right)$ & $\left(1.79 \cdot 10^{-6}\right)$ & $\left(1.70 \cdot 10^{-6}\right)$ \\
\hline
\end{tabular}

Standard errors are in parentheses. Significantly different from zero at $1 \%\left({ }^{\mathrm{a}}\right), 5 \%\left({ }^{\mathrm{b}}\right)$, and $10 \%\left({ }^{c}\right)$ level.

Table 6

Tests on Standardized Residuals

\begin{tabular}{ccccccc}
\hline Statistics & GBP & ATS & DEM & USD & CHF & FRF \\
\hline Mean & 0.006 & 0.008 & 0.016 & 0.003 & 0.009 & 0.006 \\
\hline Variance & 1.117 & 1.012 & 1.056 & 1.129 & 1.004 & 1.004 \\
\hline Skewness & -1.284 & -0.212 & 0.017 & 1.370 & 0.031 & -0.547 \\
\hline Kurtosis & 12.795 & 1.028 & 3.200 & 12.436 & 0.885 & 1.772 \\
\hline $\mathrm{nQ}(10)$ & 8.427 & 2.443 & 2.522 & 2.918 & 1.572 & 4.411 \\
\hline $\mathrm{nQ}^{2}(10)$ & 1.637 & 20.826 & 4.246 & 6.152 & 11.850 & 19.144 \\
\hline
\end{tabular}

Ljung-Box: critical value of 23.21 from $\chi^{2}$ distribution with 10 d.f. at $1 \%$ level is used. 
Table 7

BDS Test: First Logarithmic Differences

\begin{tabular}{cccccccc}
\hline $\mathrm{m}$ & $\varepsilon$ & ATS & GBP & DEM & USD & CHF & FRF \\
\hline 2 & 1 & $8.72^{*}$ & $7.86^{*}$ & $3.70^{*}$ & 1.19 & $3.64^{*}$ & $4.72^{*}$ \\
\hline 3 & 1 & $10.3^{*}$ & $10.2^{*}$ & $4.11^{*}$ & 1.09 & $4.18^{*}$ & $5.68^{*}$ \\
\hline 4 & 1 & $11.7^{*}$ & $12.0^{*}$ & $4.90^{*}$ & 1.62 & $4.88^{*}$ & $6.93^{*}$ \\
\hline 5 & 1 & $12.7^{*}$ & $13.27^{*}$ & $5.62^{*}$ & $2.34^{*}$ & $5.74^{*}$ & $8.12^{*}$ \\
\hline 6 & 1 & $14.21^{*}$ & $14.39^{*}$ & $6.43^{*}$ & $3.19^{*}$ & $6.46^{*}$ & $9.57^{*}$ \\
\hline 7 & 1 & $16.25^{*}$ & $15.28^{*}$ & $7.30^{*}$ & $3.89^{*}$ & $6.92^{*}$ & $11.36^{*}$ \\
\hline 8 & 1 & $18.50^{*}$ & $16.23^{*}$ & $8.06^{*}$ & $4.46^{*}$ & $7.28^{*}$ & $12.76^{*}$ \\
\hline 9 & 1 & $21.13^{*}$ & $17.26^{*}$ & $9.10^{*}$ & $5.06^{*}$ & $7.48^{*}$ & $14.36^{*}$ \\
\hline 10 & 1 & $24.01^{*}$ & $18.40^{*}$ & $10.32^{*}$ & $5.56^{*}$ & $7.45^{*}$ & $15.87^{*}$ \\
\hline & & & & & & & \\
\hline 2 & $1 / 2$ & $2.87^{*}$ & $6.27^{*}$ & $3.69^{*}$ & 1.91 & $3.35^{*}$ & $7.18^{*}$ \\
\hline 3 & $1 / 2$ & $2.68^{*}$ & $7.80^{*}$ & $3.83^{*}$ & 1.74 & $4.06^{*}$ & $8.59^{*}$ \\
\hline 4 & $1 / 2$ & $2.39^{*}$ & $9.31^{*}$ & $4.48^{*}$ & 2.19 & $4.56^{*}$ & $10.45^{*}$ \\
\hline 5 & $1 / 2$ & 1.96 & $10.20^{*}$ & $5.03^{*}$ & $2.61^{*}$ & $4.84^{*}$ & $12.35^{*}$ \\
\hline 6 & $1 / 2$ & 2.18 & $10.88^{*}$ & $5.36^{*}$ & $3.31^{*}$ & $4.92^{*}$ & $15.89^{*}$ \\
\hline 7 & $1 / 2$ & $3.10^{*}$ & $11.28^{*}$ & $6.24^{*}$ & $2.65^{*}$ & $6.03^{*}$ & $21.01^{*}$ \\
\hline 8 & $1 / 2$ & $3.34^{*}$ & $11.73^{*}$ & $5.27^{*}$ & $3.81^{*}$ & $6.06^{*}$ & $26.91^{*}$ \\
\hline 9 & $1 / 2$ & $5.16^{*}$ & $12.67^{*}$ & $2.99^{*}$ & $3.19^{*}$ & $4.37^{*}$ & $35.85^{*}$ \\
\hline 10 & $1 / 2$ & $6.82^{*}$ & $13.43^{*}$ & 1.60 & $8.44^{*}$ & -2.66 & $50.24^{*}$ \\
\hline
\end{tabular}

BDS follows t-distribution. * indicates $1 \%$ significance level (> 2.33). 
Table 8

BDS Tests of Nonlinearity: Standardized Residuals

$\operatorname{GARCH}(1,1)$

\begin{tabular}{cccccccc}
\hline $\mathrm{m}$ & $\varepsilon$ & GBP & ATS & DEM & USD & CHF & FRF \\
\hline 2 & 1 & -1.92 & -0.51 & -1.10 & -0.84 & 0.79 & -0.53 \\
\hline 3 & 1 & $-2.02^{*}$ & -0.68 & -1.37 & -1.27 & 0.75 & -1.09 \\
\hline 4 & 1 & $-1.61^{*}$ & -0.47 & -1.37 & $-1.43^{*}$ & 0.79 & -1.23 \\
\hline 5 & 1 & $-1.78^{*}$ & -0.66 & -1.35 & $-1.50^{*}$ & 0.98 & -1.20 \\
\hline 6 & 1 & -1.88 & -0.71 & -1.40 & -1.55 & 1.07 & -1.06 \\
\hline 7 & 1 & -2.19 & -0.71 & -1.47 & -1.44 & 1.11 & -0.77 \\
\hline 8 & 1 & -2.37 & -0.71 & -1.51 & -1.32 & 0.97 & -0.92 \\
\hline 9 & 1 & -2.52 & -0.69 & -1.41 & -1.22 & 0.59 & -0.93 \\
\hline 10 & 1 & $-2.63 *$ & -0.64 & -1.46 & -1.15 & 0.23 & -0.94 \\
\hline & & & & & & & \\
\hline 2 & 0.5 & -1.95 & 0.20 & -0.51 & -1.26 & 1.01 & -0.87 \\
\hline 3 & 0.5 & $-2.09 *$ & 0.21 & -1.02 & -1.73 & 0.84 & -1.37 \\
\hline 4 & 0.5 & -1.71 & -0.01 & -0.97 & -1.80 & 0.92 & -1.38 \\
\hline 5 & 0.5 & -2.11 & -0.37 & -0.93 & -1.86 & 0.27 & -1.72 \\
\hline 6 & 0.5 & -2.09 & -0.50 & -1.80 & -2.14 & -0.69 & -1.66 \\
\hline 7 & 0.5 & -1.77 & -0.63 & -1.36 & -1.99 & -1.83 & -1.19 \\
\hline 8 & 0.5 & -1.85 & -0.57 & -1.12 & -1.20 & -3.69 & -0.69 \\
\hline 9 & 0.5 & -2.57 & 1.66 & -2.02 & -0.72 & -4.59 & -0.67 \\
\hline 10 & 0.5 & -1.14 & 4.99 & -0.60 & -1.72 & -4.48 & -2.21 \\
\hline
\end{tabular}

BDS: critical values in a form of Quantiles of BDS Statistic are provided in a separate Table 9.

Table 9

Quantiles of BDS Statistic

GARCH(1,1) Standardized Residuals 1000 Observations

\begin{tabular}{|c|c|c|c|c|c|c|}
\hline Quantile & & & $\mathrm{m}$ & & & \\
\hline & 2 & 3 & 4 & 5 & 10 & $\mathrm{~N}(0,1)$ \\
\hline \multicolumn{7}{|l|}{$\varepsilon=1.0 \sigma$} \\
\hline $1.0 \%$ & -1.97 & -1.64 & -1.42 & -1.45 & -1.66 & -2.33 \\
\hline $2.5 \%$ & -1.69 & -1.41 & -1.26 & -1.20 & -1.46 & -1.96 \\
\hline $97.5 \%$ & 1.63 & 1.42 & 1.32 & 1.23 & 1.75 & 1.96 \\
\hline $99.0 \%$ & 2.01 & 1.78 & 1.61 & 1.51 & 2.23 & 2.33 \\
\hline \multicolumn{7}{|l|}{$\varepsilon=0.5 \sigma$} \\
\hline $1.0 \%$ & -2.11 & -1.96 & -2.09 & -2.45 & -7.31 & -2.33 \\
\hline $2.5 \%$ & -1.84 & -1.72 & -1.80 & -2.05 & -6.93 & -1.96 \\
\hline $97.5 \%$ & 1.80 & 1.79 & 1.92 & 2.19 & 16.83 & 1.96 \\
\hline $99.0 \%$ & 2.29 & 2.18 & 2.25 & 2.69 & 23.48 & 2.33 \\
\hline
\end{tabular}

Based on 2000 replications. Source: Brock, Hsieh, and LeBaron (1993), p. 278 